\title{
El derecho de voto como derecho fundamental
}

\section{The Right to Vote as a Fundamental Right}

\section{Miguel Ángel Presno Linera*}

\section{Sumario:}

I. El derecho de voto como derecho fundamental

II. El objeto del derecho de voto, su ejercicio y las formas de ejercerlo

III. El desarrollo legislativo del derecho de voto

IV. La titularidad del derecho de voto y las abstracciones necesarias para garantizar su carácter universal

V. La condena penal no debe suspender la ciudadanía: los presos también son importantes

* Profesor de Derecho Constitucional en la Universidad de Oviedo.

Recibido: 22 de abril de 2012 Aceptado: 13 de mayo de 2012 


\section{Resumen:}

En este artículo se estudia el derecho de voto o de sufragio como un derecho fundamental para la participación política, su objeto y las formas habilitadas para su ejercicio. También su necesario desarrollo legislativo y qué personas deben poder ejercerlo, incluyendo a los extranjeros, los miembros de la policía y las fuerzas armadas y los presos en instituciones penitenciarias.

\section{Abstract:}

In this paper we study the right to vote as a fundamental right to political participation, its purpose and how to exercise it. Also the development of voting rights legislation and what people should be able to vote, including foreigners, policemen, soldiers and prisoners.

Palabras clave: derechos fundamentales, derecho electoral, derecho de participación política, derecho de voto.

Descriptors: fundamental rights, electoral law, right of political participation, right to vote. 


\section{El derecho de voto como derecho fundamental}

El derecho de voto es el derecho político fundamental porque garantiza todos los demás derechos ${ }^{1}$

Como es bien sabido, el sufragio ya fue incluido en las primeras declaraciones de derechos, desde el Bill of Rights, del 13 de febrero de 1689 (8. "La elección de los miembros del Parlamento debe ser libre"), la Declaración de derechos hecha por los representantes del buen pueblo de Virginia, aprobada el 12 de junio de 1776 (VI. “Todas las elecciones de representantes del pueblo en la asamblea deben ser libres; y que todos los hombres que hayan probado suficientemente su adhesión a la comunidad y un interés permanente con ella tienen derecho de sufragio, y no podrán ser gravados con impuestos o privados de su propiedad para uso público sin su propio consentimiento o el de sus representantes así elegidos, ni obligados por ninguna ley que no hayan consentido para el bien público") hasta la Declaración de Derechos del Hombre y del Ciudadano, del 26 de agosto de 1789 (artículo 6: "La Ley es la expresión de la voluntad general. Todos los ciudadanos tienen el derecho de participar personalmente, o por medio de sus representantes, en su formación. Debe ser la misma para todos, tanto si protege como si castiga. Todos los ciudadanos, al ser iguales ante ella, son igualmente admisibles en todas las dignidades, puestos y empleos públicos, según su capacidad y sin otra distinción que la de sus virtudes y la de sus talentos").

Pero, a diferencia de lo que sucedió en la época liberal, en la que la intervención de los individuos en el ejercicio del poder desempeñaba, en última instancia, una función legitimadora de las limitaciones impuestas por el legislador a la libertad "natural" de las personas, en un sistema democrático ese derecho a participar en los asuntos públicos no desempeña una mera función de legitimación, sino que canaliza el flujo de expectativas políticas de la sociedad al Estado, con lo que la comunidad se autodetermina de manera constante y puede decidir el sentido de su orientación política.

El derecho a ejercer esta forma de autogobierno es un atributo reconocido a los integrantes de una sociedad determinada y una garantía

1 Tribunal Supremo de Estados Unidos, Yick Wo v. Hopkins, 118 U.S. 356, del 10 de mayo de 1886, http://supct.law.cornell.edu/supct/html/historics/USSC_CR_0118_0356_ ZO.html. 
de la propia existencia democrática de esa comunidad. No se trata de fundamentar el voto en un supuesto derecho natural preexistente a la organización del poder político, sino de aceptar que ese poder sólo es democrático si se ejercita y desarrolla según la orientación que le otorgan en cada momento los destinatarios inmediatos de sus decisiones.

La extraordinaria importancia de este derecho ha sido puesta de relieve en distintas latitudes y culturas jurídicas, tanto en textos doctrinales - ya Rousseau sostuvo en 1762 en El contrato social que el derecho de votar es un derecho que nadie puede quitar a los ciudadanos ${ }^{2}$ y Madison afirmó en El Federalista (LII) que este derecho es un elemento esencial del gobierno republicano-,${ }^{3}$ internacionales ${ }^{4} \mathrm{y}$ jurisprudenciales -en Yick Wo v. Hopkins, del 10 de mayo de 1886,

2 Du Contrat social, Libro IV, Capítulo I; está disponible, entre otros sitios, en http:// abu.cnam.fr/cgi-bin/donner?contrat1; http://un2sg4.unige.ch/athena/rousseau/jjr_cont. html.

${ }^{3}$ Los textos de El Federalista pueden leerse en diversos sitios y formatos; entre otros: http://www.constitution.org/fed/federa00.htm y http://www.leftiustified.com/leftjust/lib/ sc/ht/fed/index.html.

4 “1. Toda persona tiene derecho a participar en el gobierno de su país, directamente o por medio de representantes libremente escogidos... 3. La voluntad del pueblo es la base de la autoridad del poder público; esta voluntad se expresará mediante elecciones auténticas, que habrán de celebrarse periódicamente, por sufragio universal e igual y por voto secreto u otro procedimiento equivalente que garantice la libertad del voto" (artículo 21 de la Declaración Universal de Derechos Humanos);

“Todos los ciudadanos gozarán, sin ninguna de las distinciones mencionadas en el artículo 2, y sin restricciones indebidas, de los siguientes derechos y oportunidades: Participar en la dirección de los asuntos públicos, directamente o por medio de representantes libremente elegidos; Votar y ser elegidos en elección periódicas, auténticas, realizadas por sufragio universal e igual y por voto secreto que garantice la libre expresión de la voluntad de los electores" (artículo 25 del Pacto Internacional de Derechos Civiles y Políticos);

"Las Altas Partes Contratantes se comprometen a organizar, a intervalos razonables, elecciones libres con escrutinio secreto, en condiciones que garanticen la libre expresión de la opinión del pueblo en la elección del cuerpo legislativo" (artículo 3o. del Protocolo núm. 1 del Convenio Europeo de Derechos Humanos); “Todos los ciudadanos deben gozar de los siguientes derechos y oportunidades: a) de participar en la dirección de los asuntos públicos, directamente o por medio de representantes libremente elegidos; b) de votar y ser elegidos en elecciones periódicas auténticas, realizadas por sufragio universal e igual y por voto secreto que garantice la libre expresión de la voluntad de los electores" (artículo 23 de la Convención Americana de Derechos Humanos, Pacto de San José);

"La participación de la ciudadanía en las decisiones relativas a su propio desarrollo es un derecho y una responsabilidad. Es también una condición necesaria para el pleno y efectivo ejercicio de la democracia..." (artículo 6 de la Carta Democrática Interamericana). 
el Tribunal Supremo de Estados Unidos consideró que "el derecho de voto es el derecho político fundamental porque garantiza todos los demás derechos" $-{ }^{5}$ y en Yatama $v$ s. Nicaragua, ${ }^{6}$ del 23 de junio de 2005, la Corte Interamericana de Derechos Humanos señaló que:

Los derechos políticos protegidos en la Convención Americana, así como en diversos instrumentos internacionales, propician el fortalecimiento de la democracia y el pluralismo político... El derecho al voto es uno de los elementos esenciales para la existencia de la democracia y una de las formas en que los ciudadanos ejercen el derecho a la participación política.

En un sistema democrático el voto es, pues, un "derecho", un poder reconocido por el ordenamiento a los individuos para que intervengan en la adopción de las decisiones políticas y en la formación de las normas a través de las que se expresa la voluntad popular. Desde una perspectiva jurídica, más que la participación efectiva lo que importa es la garantía de la misma, que se construye a partir de normas que aseguren el derecho a decidir, así como la libertad y la igualdad de la decisión. El componente de derecho significa que ese poder de decisión que se confiere al individuo es un fin en sí mismo, garantizando la posibilidad de participar y, sobre todo, que la decisión tenga consecuencias jurídicas, debiendo de imponerse como resultado con

5118 U.S. 356; varias décadas después el Tribunal Supremo recordó que "en un país libre ningún derecho es más importante que el de poder hacerse oír en la elección de los que aprobarán las leyes bajo las que debemos vivir como buenos ciudadanos. Los demás derechos, incluso los más esenciales, resultarán ilusorios si el derecho de voto se ve menoscabado (Reynolds v. Sims, 377 U.S. 533, del 15 de junio de 1964); ambas sentencias puede leerse en la página gestionada en la Universidad de Cornell; la primera en $h t t p: / /$ supct.law.cornell.edu/supct/html/historics/USSC_CR_0118_0356_ZO.html y la segunda en http://supct.law.cornell.edu/supct/html/historics/USSC_CR_0377_0533_ZO.html.

Para el Tribunal Europeo de Derechos Humanos (Asunto Hirst c. Reino Unido (núm. 2), del 6 de octubre de 2005, es crucial "para el establecimiento y la conservación de los fundamentos de una democracia auténtica regida por el Estado de derecho"; disponible en http://cmiskp.echr.coe.int/; en suma, como declara el Tribunal Supremo de Canadá (Sauvé c. Canada -Chief Electoral Officer-), del 31 de octubre de 2002, "los derechos garantizados par la Carta no son una cuestión de privilegio o de mérito, sino de pertenencia a la sociedad canadiense que no puede ser obviada a la ligera, lo que es particularmente cierto en el derecho de voto, piedra angular de la democracia...."; puede leerse en $h t t p: / / s c c . l e x u m . u m o n t r e a l . c a / f r / 2002 / 2002 \csc 68 / 2002 c s c 68 . h t m l$ en francés y http:// scc.lexum.umontreal.ca/en/2002/2002scc68/2002scc68.html en inglés.

${ }_{6}$ http://www.corteidh.or.cr/docs/casos/fundamentos/jseriec127.pdf. 
la mayor correspondencia posible con la voluntad manifestada por el pueblo.

Con su incorporación a la Constitución, este derecho alcanza además el rango de fundamental, lo que, como es obvio, significa, como ya dijo en 1803 el Tribunal Supremo de los Estados Unidos en el caso Marbury vs. Madison, ${ }^{7}$ que "se impone sobre cualquier disposición legislativa que le sea contraria”, sea de ámbito estatal o regional. ${ }^{8} \mathrm{El} \mathrm{ca-}$ rácter "fundamental" de la participación se deriva, pues, de su inclusión en la norma superior del ordenamiento, que le otorga un objeto y un contenido determinados, sobre los que el legislador podrá realizar determinadas concreciones, pero siempre en el marco impuesto por el texto constitucional. Este rasgo es característico de las Constituciones democráticas, lo que impide que se produzca el fenómeno, frecuente durante el siglo XIX, de que el contenido del voto sea determinado por el legislador ante el silencio de la norma suprema, y evita también que se puedan articular restricciones no admitidas ni queridas por el constituyente. $^{9}$

El voto representa un ejemplo de derecho fundamental que no va a poder ser ejercido por el titular del mismo sin una previa intermediación del legislador, lo que no impide afirmar que su incorporación al texto constitucional supone una disponibilidad potencialmente inmediata, que se concreta en la posibilidad de exigir que los poderes públicos arbitren la organización y los procedimientos necesarios para

7 Puede leerse, entre otros sitios, en $\mathrm{http}$ ://laws.findlaw.com/us/5/137.html; traducida al castellano en http://www.der.uva.es/constitucional/verdugo/marbury_madison.html.

8 Véase Bastida et al., Teoría general de los derechos fundamentales en la Constitución Española de 1978, Madrid, Tecnos, 2004, pp. 30 y ss.

9 Como ha dicho el Tribunal Supremo de Canadá, "la analogía que establece [el Gobierno] entre las restricciones al derecho de voto de los menores y la supresión del derecho de los presos no es procedente, pues la decisión que adopta el Legislador en los dos casos es bien diferente. En el primer caso, toma una decisión basada en la situación empírica en las que se encuentran los ciudadanos mientras son menores; esta decisión no significa que la categoría excluida no sea digna de votar, sino que establece una forma de aplicación del sufragio universal; en el segundo caso, decide que ciertas personas, con independencia de su capacidad, no son dignas, moralmente, de votar; no "merecen" ser consideradas miembros de la comunidad... Pero no le corresponde al Legislador tomar esta decisión; la Carta la ha tomado por nosotros, garantizando el derecho de voto a "todo ciudadano", colocando expresamente a los presos bajo su protección... La Carta afirma categóricamente que los presos son ciudadanos protegidos, y en ausencia de una reforma constitucional, el Legislador no puede cambiarlo..., Sauvé c. Canada -Chief Electoral Officer-, en http://scc.lexum.umontreal.ca/fr/2002/2002csc68/2002csc68.html y http://scc.lexum.umontreal.ca/en/2002/2002scc68/2002scc68.html. 
dar efectividad al derecho. La omisión o desatención de esta obligada intervención del legislador hará emerger la eficacia directa de la norma iusfundamental, aunque sea en su contenido mínimo o esencial, lo que en la actualidad, como veremos con detalle más adelante, puede tener especial relevancia para determinados titulares del derecho de sufragio, como los ciegos o las personas que están en situación de detención policial. ${ }^{10}$

En suma, el derecho fundamental de voto es un derecho subjetivo; es decir, un apoderamiento jurídico (contenido del derecho) que la Constitución atribuye a un sujeto para que pueda defender, asegurar o ejercer determinadas expectativas de participación política (objeto del derecho). Con la fuerza normativa de la Constitución, ese apoderamiento consistirá en la posibilidad de exigir a los poderes públicos que aseguren la intervención de manera directa o a través de representantes en el gobierno político de la comunidad. ${ }^{11}$

La "fundamentalidad" que la Constitución confiere a este derecho significa que lo dota de una disponibilidad para su titular potencialmente inmediata, $y$, como fuente de las demás fuentes del ordena-

10 Así, y a propósito del sufragio de los invidentes en condiciones de libertad e igualdad que el resto de los titulares del derecho, la Corte Constitucional de Colombia concluyó que "el aislamiento del ejercicio de los derechos políticos de los ciudadanos limitados físicamente, significaría soslayar las anteriores normas constitucionales dado que el distanciamiento de la vida, en su dimensión política, coloca en situación de discriminación a un sector deprimido del pueblo. En este orden de ideas, el aparato estatal debe crear el ambiente propicio en el cual las personas con limitaciones físicas puedan desenvolverse con la dignidad humana que las caracteriza... Las anteriores razones son suficientes para que esta Sala, en la parte resolutiva de esta providencia, ordene a la Registraduría Nacional del Estado Civil, para que con miras a las elecciones futuras implemente el sistema Braille en los tarjetones, de tal manera que se permita ejercer el derecho al sufragio a las personas que necesiten de este medio sin necesidad de estar acompañadas; permitiéndole al mismo tiempo a aquellos ciudadanos invidentes que no deseen usar o que no conozcan dicho sistema, que sigan ejerciendo el derecho al voto con un acompañante (Sentencia T-473/03 de 9 de junio de 2003)", en http://www.ramajudicial.gov.co/csj_portal/.

Respecto al sufragio de las personas detenidas, la Corte Suprema de Justicia de Argentina (Mignone, Emilio F., sentencia del 14 agosto de 2002) concluyó que "corresponde urgir al Poder Legislativo y al Poder Ejecutivo a que adopten las medidas necesarias para hacer efectivo el derecho a votar de los detenidos no condenados y en este marco, esta Corte considera prudente disponer que este derecho sea implementado por las autoridades competentes dentro del plazo de seis meses"; véase en http://www.csjn.gov.ar/.

11 El Tribunal Superior Eleitoral de Brasil habla del "carácter autoaplicativo" de la Constitución en relación con la inclusión de los mayores de 16 años a efectos del sufragio; Resolución 15.072, del 28 de febrero de 1989; http://www.tse.gov.br. 
miento, lo preserva de su alteración o vulneración por normas infraconstitucionales y lo hace indisponible para el legislador e, incluso, para el órgano de reforma constitucional, como ocurre, por citar dos ejemplos, con la Constitución de la República Federal de Alemania (artículo 79.3) ${ }^{12}$ y la Constitución de Portugal (artículo 288), ${ }^{13}$ que declaran irreformables, entre otros, los preceptos relativos al derecho de voto.

El contenido subjetivo del derecho de voto, entendido como el haz de facultades jurídicas atribuidas a su titular, no se incluye de manera exclusiva en el concreto precepto constitucional que lo enuncia, ${ }^{14}$

12 De acuerdo con ese artículo, "no está permitida ninguna modificación de la presente Ley Fundamental que afecte la organización de la Federación en Länder, o el principio de la participación de los Länder en la legislación, o los principios enunciados en los artículos 1 y 20 ” y en el artículo 20 se proclama que "1. la República Federal de Alemania es un Estado federal democrático y social. 2. Todo poder del Estado emana del pueblo. Este poder es ejercido por el pueblo mediante elecciones y votaciones y por intermedio de órganos especiales de los poderes legislativo, ejecutivo y judicial. 3. El poder legislativo está sometido al orden constitucional; los poderes ejecutivo y judicial, a la ley y al Derecho. 4. Contra cualquiera que intente eliminar este orden todos los alemanes tienen el derecho de resistencia cuando no fuere posible otro recurso".

13 "Las leyes de revisión constitucional deberán respetar: a) La independencia nacional y la unidad del Estado; $b$ ) La forma republicana de gobierno; c) La separación de las Iglesias y el Estado; $d$ ) Los derechos, libertades y garantías de los ciudadanos; e) Los derechos de los trabajadores, de las comisiones de trabajadores y de las asociaciones sindicales; f) La coexistencia del sector público, del sector privado y del sector cooperativo y social de propiedad de los medios de producción; $g$ ) La existencia de planes económicos en el ámbito de una economía mixta; $h$ ) El sufragio universal, directo, secreto y periódico en la designación de los titulares electivos de los órganos de soberanía, de las regiones autónomas y del gobierno local, así como el sistema de representación proporcional; i) El pluralismo de expresión y organización política, incluyendo los partidos políticos, y el derecho de oposición democrática...”.

${ }^{14}$ El artículo 37 de la Constitución argentina; los artículos 11 y 26 de la boliviana; 14 de la brasileña; 15 de la chilena; 40 y 258 de la colombiana; 93 de la costarricense; 88 de la dominicana; 62 de la ecuatoriana; 23 de la Española; enmiendas XV, XIX, XXIV y XXVI de la estadounidense; 136 de la guatemalteca; 44 de la hondureña; 35, 36 y 41 de la mexicana; 2 de la nicaragüense; 129 de la panameña; 118 y siguientes de la paraguaya; 31 de la peruana; 48 de la portuguesa; 78 de la salvadoreña; 78 de la uruguaya; 62 y siguientes de la venezolana.

Estos textos pueden consultarse, entre otros sitios, en las siguientes páginas: http:// www.cervantesvirtual.com/portal/constituciones/constituciones.shtml; Instituto de Investigaciones Jurídicas UNAM: http://www.juridicas.unam.mx/infojur/leg/inflegin.htm; el Poder Legislativo en América Latina: http://iberoame.usal.es/legislativo/legislativos/ Normasyreglamentos/normasyreglamentos.htm, y en http://pdba.georgetown.edu/Consti tutions/constudies.html. 
sino que su objeto, contenido y límites habrán de deducirse además de otros preceptos, en especial, de los que proclaman el carácter democrático del Estado, de los que regulan la elección de los distintos órganos de extracción política y, en su caso, de los que prevén formas de democracia directa. La necesidad de acudir a otros enunciados normativos para averiguar en qué consiste este derecho se deriva de una característica presente, en mayor o menor medida, en todos los derechos fundamentales: la peculiar estructura abstracta y abierta de sus formulaciones en los preceptos constitucionales que los contienen. ${ }^{15}$

Por este motivo es necesario precisar cuál es el objeto del derecho de voto reconocido en los textos constitucionales de referencia y esta tarea, en absoluto sencilla, exige conocer el modelo o modelos dogmáticos que están presentes en esa definición abstracta y, de manera previa, saber cuál es la concepción constitucional sobre la que se sustentan esas dogmáticas; en palabras de Ernst W. Böckenförde, la "concepción constitucionalmente adecuada". ${ }^{16}$

La importancia de mantener una teoría de los derechos fundamentales conforme a la Constitución aumenta, si cabe, en el examen del contenido esencial de los derechos, porque, si se prescinde de esa referencia, las teorías o modelos dogmáticos se autonomizan y la averiguación de tal contenido probablemente discurra por las categorías doctrinales elaboradas en el interior de dichos modelos, al margen de una explícita referencia constitucional o por remisión a principios funcionales de la Constitución, entendida ésta no como norma, sino como instrumento político de integración y de estabilidad del orden.

15 Como explica Ignacio de Otto, el carácter abstracto de la definición de los derechos deriva, "por una parte, de que ésta se hace mencionando genéricamente una conducta que en la realidad ha de transcurrir siempre como algo concreto, susceptible de múltiples modalidades y, de otra, de que la definición del derecho se hace prescindiendo de la pluralidad de facultades con que puede alcanzarse el fin al que el derecho sirve como instrumento; "La regulación del ejercicio de los derechos y libertades. La garantía de su contenido esencial en el artículo 53.1 de la Constitución”, en Martín-Retortillo, Lorenzo y de Otto y Pardo, Ignacio (eds.), Derechos fundamentales y Constitución, Madrid, Civitas, 1988, p. 157.

16 "Die Methode der Verfassungsinterpretation-Bestandsaufnahme und Kritik", en Neue Juristische Wochenschrift, Heft 46, 1976, p. 2098.; sobre esta metodología véase también su "Grundrechtstheorie und Grundrechtsinterpretation", Neue Juristische Wochenschrift, Heft 35, 1974, pp. 1529 y ss. Estos trabajos están incluidos en la traducción de los Escritos sobre derechos fundamentales realizada por Juan Luis Requejo Pagés e Ignacio Villaverde Menéndez para Nomos, Baden-Baden, 1993, pp. 13 y ss., 44 y ss. 
El proceso de determinación de cuál es la dogmática adecuada no puede consistir, como es obvio, en que el intérprete lo decida por sí mismo, pues si así fuera se estaría proyectando la concepción personal sobre la Constitución y los derechos fundamentales para, de esta manera, acomodar el precepto a esa compresión previa del derecho. El texto constitucional tiene que ser el punto de partida y no el de llegada de la tarea interpretativa, por lo que ésta ha de partir de lo que al respecto se haya establecido en aquél. Esto es lo que explica la especial atención que se debe prestar a uno de los principios estructurales de la norma fundamental, el democrático, que se irradia a la totalidad del ordenamiento constitucional, y, en particular, a un derecho como el de sufragio.

Como es obvio, las consideraciones que aquí se hacen toman como referencia los preceptos de las Constituciones que son objeto de mención, si bien puede ocurrir que no se puedan aplicar en su integridad a todas ellas.

\title{
II. El objeto del derecho de voto, su ejercicio y las formas de ejercerlo
}

\author{
Democracia significa identidad entre dirigentes \\ y dirigidos, entre sujeto y objeto del poder del Estado, \\ y gobierno del pueblo por el pueblo \\ Hans Kelsen, Von Wesen und Wert der Demokratie, 1929
}

Es necesario, antes de entrar en el análisis del objeto, ejercicio e instrumentos de realización del derecho de voto, aclarar qué se va a entender aquí por objeto y ejercicio de los derechos fundamentales. La tesis que aquí se comparte es la que sostiene que el objeto de un derecho es lo definido de manera abstracta en una serie de enunciados constitucionales, donde se incluyen las facultades o posibilidades de actuación y los límites a las mismas necesarios para identificar el derecho. El ejercicio del derecho consiste en llevar a cabo alguna de las conductas posibles del mismo o de las facultades para su defensa o mejor realización ${ }^{17} \mathrm{y}$, puesto que el ejercicio de los derechos no es otra

${ }_{17}$ Definiciones propuestas por Villaverde Menéndez, Ignacio, "Esbozo de una teoría general de los derechos fundamentales”, Revista Jurídica de Asturias, núm. 22, 1998, pp. 33 y ss., en concreto p. 36. 
cosa que la realización de aquel objeto, no es admisible el establecimiento de disciplinas distintas para uno y otro. La diferencia entre el objeto concreto de un derecho y la esfera de su ejercicio, no expresa otra cosa que la fisonomía estática y dinámica del ámbito normativo en que el derecho consiste.

Dicho lo anterior, debe precisarse ahora cuál es el objeto que el texto constitucional atribuye al derecho de voto. Como se ha indicado más arriba, no siempre es algo que quepa extraer del mero análisis del concreto artículo de la norma fundamental que lo reconoce, sino que al tiempo han de tenerse en cuenta otros preceptos relativos a este derecho y, en especial, aquéllos en los que se establece el carácter democrático del Estado.

Para esclarecer el objeto de un derecho fundamental es necesario, en primer lugar, identificar el ámbito de la realidad aludido y lo que no forma parte del mismo y, en segundo término, averiguar cuál es el tratamiento jurídico derivado del precepto o preceptos que reconocen el derecho. ${ }^{18}$

En el derecho que nos ocupa, el ámbito garantizado es la autodeterminación política de los individuos que están sujetos a un determinado sistema jurídico; lo que asegura este derecho es la facultad de intervenir en los asuntos políticos, por lo que queda fuera del voto, aunque puede estar protegida por otro derecho, la participación que no es política; en segundo lugar, esa intervención ha de realizarse de manera directa o por medio de representantes elegidos con libertad en elecciones periódicas por sufragio universal.

De los enunciados constitucionales resulta que el sufragio no se limita a la elección o a la votación, no se agota en la libertad misma (el acto de votar), sino que se dirige a que la voluntad de los individuos se convierta en voluntad del Estado.

De esta manera, el voto permite la realización de los valores del ordenamiento relacionados con la democracia: la libertad, la igualdad y el pluralismo político. Sirve a la libertad porque se concibe como la expresión, manifestada de manera autónoma y voluntaria, de la opción personal sobre el modo en que debe desarrollarse la ordenación política del sistema social; a la igualdad porque se atribuye el mismo valor a todos los actos de participación, como consecuencia del

${ }_{18}$ Sobre estas operaciones, véase Ignacio de Otto, "La regulación del ejercicio..., cit., p. 142. 
idéntico valor de todas las opciones, lo que a su vez tiene relación directa con el pluralismo político, que se define como la garantía de la existencia de distintas maneras de entender la organización del poder político dentro de la sociedad y la atribución a todas ellas de similares posibilidades de realización práctica. Así, se realiza la democracia y, al tiempo, se asegura la autonomía del proceso político respecto de otros procesos que se desarrollan dentro del sistema social, autonomía que resulta fundamental para la "legitimación mediante procedimientos" y la consiguiente reducción de la complejidad social. ${ }^{19}$

La autodeterminación política de los individuos, su posibilidad de decidir sobre el contenido de las normas a las que van a estar sometidos, se realiza, se ejercita, tomando parte en los procesos de elaboración y aprobación de las decisiones relativas al desempeño del poder, conformando así el estatuto político de la comunidad y a la propia comunidad como una entidad política. No en vano eso es lo que significa "participar": tomar o ser parte, y la intervención de la parte, el individuo, en la toma de decisiones es lo que hace posible la existencia del todo, de la comunidad política. Y nuestra comunidad política, jurídicamente organizada, en tanto asume como uno de sus principios constitutivos la democracia, a su vez se compromete a favorecer la intervención de los individuos, lo que sin duda contribuye a dotar de carácter "autorreferencial” al sistema. Esta participación constituye la vertiente dinámica de la autodeterminación política y a su vez se concreta en las formas previstas en los textos constitucionales para su ejercicio, con lo que estos medios de realización, de ejercicio del derecho, se integran en su contenido constitucional y gozan de las mismas garantías.

Ahora bien, como ya se ha dicho, el primer elemento para la determinación del objeto del derecho de voto es la identificación de la realidad aludida; en nuestro caso, la participación de la que se está hablando no es todo tipo de intervención en los asuntos públicos cualquiera que sea su índole y condición. Ha de ser "política", como expresión del ejercicio de la soberanía, y esta exigencia se cumple bien cuando los ciudadanos se pronuncian de manera inmediata sobre la aprobación o derogación de una norma jurídica (referéndum abrogativo o derogativo) ${ }^{20}$ o se mani-

19 Sobre la capacidad legitimadora de los procedimientos, véase Luhmann, Niklas, Legitimation durch Verfahren (3. Auflage), Luchterhand, Darmstadt-Neuwied, 1978, pp. 73 y ss., 159 y ss.

20 Es clave en esta materia la sentencia del Tribunal Constitucional italiano del 2 de febrero de 1978, que extraemos en la segunda parte; nos hemos ocupado de esta cues- 
fiestan acerca de una decisión política, o bien a través de los procesos para la elección de cargos de representación política.

Como es obvio, también existen otras formas de participación política reconocidas en los textos constitucionales de los Estados democráticos, como la creación de partidos o la presentación de iniciativas legislativas, pero no se trata de formas de ejercicio del derecho de voto. Y, además, se reconocen formas de participación, como la que ejercitan los trabajadores en los procesos electorales sindicales, que no son "políticas" y, por lo tanto, no forman parte del conjunto de conductas protegidas por la Constitución dentro del derecho de sufragio. ${ }^{21}$

La exclusión de los supuestos mencionados, o de otros similares, se debe a que en ellos no concurren dos exigencias necesarias: en primer término, el carácter político de la participación. Para determinar si estamos o no ante el derecho de voto encuadrable en la participación política habrá que atender, no sólo a la naturaleza y forma del llamamiento, sino también a su finalidad: sólo allí donde la llamada a la

tión en Presno Linera, Miguel A. y Campione, Roger, Las sentencias básicas del Tribunal Constitucional italiano. Estudio de una jurisdicción de la libertad, Madrid, CEPC, 2009; la sentencia puede leerse íntegra en la dirección electrónica del Tribunal: http://www. cortecostituzionale.it/giurisprudenza/pronunce/filtro.asp.

${ }^{21}$ Como ha dicho el Tribunal Constitucional español (STC 189/1993, de 14 de junio): “5... Se ha de señalar que ninguna vulneración del artículo 23.1 de la Constitución española entraña el cómputo de las horas dedicadas al ejercicio del derecho de elección de los representantes de los trabajadores en la empresa, esto es, el tiempo invertido en participar en las denominadas «elecciones sindicales», a efectos de la mencionada cláusula del Convenio Colectivo, pues el ejercicio de tal derecho no está amparado por el mencionado derecho al sufragio (artículo 23.1 C. E.), encontrando sólo una directa vinculación en el artículo 129.2 de la Constitución española, como una manifestación de las «diversas formas de participación en la empresa» (SSTC 98/1985, 208/1989 y 197/1990). Ha de tenerse en cuenta que los órganos de representación unitaria y electiva en la empresa no son estructuras de participación de los ciudadanos en la vida política, sino instancias organizativas de los trabajadores en los asuntos de empresa. Lo que ejercitan los trabajadores en los procesos electorales sindicales no es una parcela subjetivizada del derecho que regula el artículo 23.1 C.E., sino un singular derecho, emanación del legislador, que se enmarca en las modalidades participativas de acceso de los trabajadores a la empresa. De suerte que al no poderse configurar el tiempo dedicado a emitir el voto para la elección de representantes unitarios en el seno de la empresa como un verdadero derecho fundamental al sufragio activo (artículo 23.1 C.E.), ha de concluirse que el cómputo de las elecciones sindicales con pérdida del incentivo por reducción del absentismo cuando se alcanza un determinado porcentaje de inasistencia a la empresa, no atenta al derecho garantizado en el artículo 23.1.... Puede leerse en http://www.tribunalconstitucional.es/ es/jurisprudencia/Paginas/Buscador.aspx. 
participación comporte, finalmente, el ejercicio, directo o por medio de representantes, del poder político — esto es, sólo allí donde se llame al pueblo como titular de ese poder- estaremos en el marco del derecho de voto, lo que no sucede, por citar un ejemplo, en las elecciones a un órgano de gobierno universitario (el rector, por ejemplo), donde los miembros del cuerpo electoral lo son por su pertenencia a la comunidad universitaria.

En segundo lugar, el reconocimiento de la facultad de participar a todos los individuos ha de basarse precisamente en la condición de sujetos a un determinado ordenamiento y, por consiguiente, en la abstracción de cualquier otra circunstancia personal, económica o social (ser trabajador asalariado, integrante de una corporación profesional, miembro de una institución universitaria....). ${ }^{22}$ No es esto lo que sucede, por seguir con el ejemplo citado, en las elecciones universitarias, dirigidas a que en su gobierno y en el de sus centros quede asegurada la representación de los diferentes sectores de la comunidad universitaria.

En definitiva, dentro de la categoría más amplia de la participación es posible distinguir la que es "política" de la que no lo es. Una vez determinados los criterios para identificar a la que sí es política, aquí únicamente nos ocupamos de la que se ejerce a través del voto, tanto en consultas de democracia directa como en las propias de la democracia representativa.

22 Como se afirma en la Sentencia del Tribunal Constitucional español núm. 11 de 1995, de 16 de enero, (STC 11/1995): "Este Tribunal ha rechazado la pretendida vinculación entre la condición de miembro de la Junta de Gobierno de una Facultad y el artículo 23 C.E. (STC 212/1993), o entre este mismo precepto y la elección de representantes sindicales, pues «lo que ejercitan los trabajadores en los procesos electorales sindicales no es una parcela subjetivizada del derecho que regula el artículo 23.1 C.E., sino un singular derecho, emanación del Legislador, que se enmarca en las modalidades participativas de acceso de los trabajadores a la empresa» (STC 189/1993, fundamento jurídico 5.). E igualmente ha concluido que los cargos de la Junta de Gobierno de un Colegio de Abogados no se encuentran incluidos entre los cargos públicos que contempla el artículo 23.2 de la Constitución (STC 23/1984), y lo mismo cabe decir del Secretario de un Colegio público (STC 80/1994)". (F. 2); puede consultarse en http://www.tribunalconstitucional. es/es/jurisprudencia/Paginas/Buscador.aspx. 


\section{El desarrollo legislativo del derecho de voto}

Cuando un pueblo empieza a poner trabas para que alguien tenga derecho al sufragio, podemos estar seguros de que tarde o temprano lo abolirá por completo. Esa es una de las reglas más invariables del comportamiento social. Cuanto más lejos se extienda el límite de los derechos de voto, tanto más fuerte

será la necesidad de ampliarlos aún más, ya que las fuerzas de la democracia se fortalecen con cada nueva concesión y sus exigencias aumentan a medida que se acrecienta su poder ${ }^{23}$

\section{Las Constituciones realizan diversas remisiones a las normas legales que han de desarrollar este derecho. ${ }^{24}$}

${ }_{23}$ Tocqueville, Alexis de, La democracia en América, 1835, vol. I, c. IV. Véase http:// classiques.uqac.ca/classiques/De_tocqueville_alexis/democratie_1/democratie_tome1. html en francés y http://xroads.virginia.edu/ HYPER/DETOC/toc_indx.html en inglés. "Del principio de soberanía popular en América"; puede leerse en francés en $h t t p: / / c l a s s i$ ques.uqac.ca/classiques/De_tocqueville_alexis/democratie_1/livre_1_p1_ch_4 y en inglés en http://xroads.virginia.edu/ HYPER/DETOC/1_ch04.htm.

${ }^{24}$ Así, el artículo 37 de la Constitución argentina "garantiza el pleno ejercicio de los derechos políticos, con arreglo al principio de la soberanía popular y de las leyes que se dicten en consecuencia. El sufragio es universal, igual, secreto y obligatorio"; el artículo 14 de la Constitución brasileña dice: "A soberania popular será exercida pelo sufrágio universal e pelo voto direto e secreto, com valor igual para todos, e, nos termos da lei..."; el artículo 103 de la Constitución de Colombia: "Son mecanismos de participación del pueblo en ejercicio de su soberanía: el voto, el plebiscito, el referendo, la consulta popular, el cabildo abierto, la iniciativa legislativa y la revocatoria del mandato. La ley los reglamentará...”; en la Constitución de Costa Rica (artículo 95) se lee: "La ley regulará el ejercicio del sufragio"; según el artículo 68.1 de la Constitución Española: "El Congreso de compone de un mínimo de 300 y un máximo de 400 Diputados, elegidos por sufragio universal, libre, igual, directo y secreto, en los términos que establezca la ley"; por su parte, el artículo 69.2 declara que: "En cada provincia se elegirán cuatro Senadores por sufragio universal, libre, igual, directo y secreto por los votantes de cada una de ellas, en los términos que señale una ley orgánica”; la Constitución de Guatemala (artículo 223) dispone que: "Todo lo relativo al ejercicio del sufragio, los derechos políticos, organizaciones políticas, autoridades y órganos electorales y proceso electoral, será regulado por la ley constitucional de la materia"; la Constitución mexicana (artículo 36) configura como deber de los ciudadanos "votar en las elecciones populares en los términos que señale la Ley"; la de Paraguay (artículo 117): "Los ciudadanos, sin distinción de sexo, tienen el derecho a participar en los asuntos públicos, directamente o por medio de sus representantes, en la forma que determine esta Constitución y las leyes"; la Constitución peruana (artículo 31) atribuye a los ciudadanos: "El derecho de ser elegidos y de elegir 
Lo que estos preceptos encomiendan a la ley no es regular el derecho, sino desarrollar la norma constitucional; con ello se atiende al mencionado problema de las normas constitucionales de reconocimiento de derechos: su carácter abstracto, que resulta de la mención genérica de las conductas, que en realidad han de transcurrir siempre como algo concreto. A esa concreción de la definición genérica y abstracta se refiere el desarrollo de los derechos fundamentales y libertades públicas, ${ }^{25} \mathrm{y}$ las leyes a las que remiten las distintas Constituciones son en el caso del derecho de voto de existencia ineludible, ${ }^{26}$ pero, como es obvio, su contenido no puede restringir el ámbito mínimo del derecho constitucionalmente garantizado, ${ }^{27}$ para cuya delimitación también han de tenerse en cuenta los compromisos internacionales asumidos por el Estado. ${ }^{28}$

libremente a sus representantes, de acuerdo con las condiciones y procedimientos determinados por ley orgánica"; la de Uruguay (artículo 77): "El sufragio se ejercerá en la forma que determine la ley”, y la de Venezuela (artículo 63): “... La ley garantizará el principio de la personalización del sufragio y la representación proporcional.” $h t t p: / / w w w . c e r$ vantesvirtual.com/portal/constituciones/constituciones.shtml; http://iberoame.usal.es/legis lativo/legislativos/Normasyreglamentos/normasyreglamentos.htm; http://www.juridicas.u nam.mx/infojur/leg/inflegin.htm; http://pdba.georgetown.edu/Constitutions/constudies. html.

${ }^{25}$ Cfr. al respecto de Otto y Pardo, Ignacio, Derecho constitucional. Sistema de fuentes, Barcelona, Ariel, 1987, p. 117; este autor se extiende sobre esta cuestión en "La regulación del ejercicio de los derechos y libertades..., op. cit.

${ }^{26}$ Sobre esta cuestión, véase el estudio de Requejo Pagés, Juan Luis, "Constitución y remisión normativa”, Revista Española de Derecho Constitucional, núm. 39, pp. 115 y ss.; en especial p. 134.

27 Ya hemos recordado que, en palabras del Tribunal Supremo de Canadá, "no le corresponde al Legislador tomar esta decisión [privar del sufragio a los presos]; la Carta la ha tomado por nosotros, garantizando el derecho de voto a "todo ciudadano", colocando expresamente a los presos bajo su protección... La Carta afirma categóricamente que los presos son ciudadanos protegidos, y en ausencia de una reforma constitucional, el Legislador no puede cambiarlo..., (Sauvé c. Canada - Chief Electoral Officer-), en http:// scc.lexum.umontreal.ca/fr/2002/2002csc68/2002csc68.html, http://scc.lexum.umontreal. ca/en/2002/2002scc68/2002scc68.html.

${ }_{28} \mathrm{Y}$ "aunque los Estados parte disponen de un margen considerable para establecer, en el marco de su sistema constitucional, las normas que han de regir las elecciones legislativas y la composición de su Parlamento y que los criterios a tener en cuenta pueden variar en función de las circunstancias históricas y políticas de cada Estado, en todo caso, estas normas no pueden excluir a determinadas personas o grupos de personas de la participación en la vida política del país; en especial de la elección del Parlamento", asunto Azizc. Chipre, Sentencia del Tribunal Europeo de Derechos Humanos del 22 de junio de 2004; disponible en http://cmiskp.echr.coe.int/. 
Como se puede comprobar en el enunciado de los preceptos citados, nos encontramos con reservas específicas que inciden en la idea de que el desarrollo "directo" de este derecho fundamental requiere la aprobación de una o varias normas legales, que al regular su ejercicio lo hacen posible, pues ni la participación en las consultas de tipo plebiscitario o en los referendos, ni la elección de los representantes políticos, pueden llevarse a cabo sin normas que disciplinen el ejercicio de este derecho constitucionalmente garantizado. ${ }^{29}$

No obstante, el grado de concreción, y el correlativo margen de discrecionalidad del legislador llamado a desarrollar las normas constitucionales, varía de manera importante en unos y otros sistemas constitucionales, siendo, como resulta evidente, menor en los supuestos en que los propios textos constitucionales contemplan el voto de un modo muy pormenorizado, y mucho mayor en aquellos casos en los que la norma suprema se pronuncia de manera más genérica. Las Constituciones de Brasil, ${ }^{30}$ Costa Rica ${ }^{31}$ y México, ${ }^{32}$ por mencionar al-

${ }_{29}$ Véase Jiménez Campo, Javier, "El Legislador de los derechos fundamentales”, Estudios de Derecho Público en Homenaje a Ignacio de Otto, Universidad de Oviedo, 1993, p. 492.

30 Artículo 14: "A soberania popular será exercida pelo sufrágio universal e pelo voto direto e secreto, com valor igual para todos, e, nos termos da lei, mediante: I. plebiscito; II. referendo; III. iniciativa popular. $\$ 10^{\circ} \mathrm{O}$ alistamento eleitoral e o voto são: I. obrigatórios para os maiores de dezoito anos; II. facultativos para: a. os analfabetos; b. os maiores de setenta anos; c. os maiores de dezesseis e menores de dezoito anos. $\$ 2 .{ }^{\circ}$ Não podem alistar-se como eleitores os estrangeiros e, durante o período do serviço militar obrigatório, os conscritos...".

31 Artículo 95: "La ley regulará el ejercicio del sufragio de acuerdo con los siguientes principios: 1. Autonomía de la función electoral; 2. Obligación del Estado de inscribir, de oficio, a los ciudadanos en el Registro Civil y de proveerles de cédula de identidad para ejercer el sufragio; 3. Garantías efectivas de libertad, orden, pureza e imparcialidad por parte de las autoridades gubernativas; 4 . Garantías de que el sistema para emitir el sufragio les facilita a los ciudadanos el ejercicio de ese derecho; 5. Identificación del elector por medio de cédula con fotografía u otro medio técnico adecuado dispuesto por ley para tal efecto; 6. Garantías de representación para las minorías. 7. Garantías de pluralismo político; 8. Garantías para la designación de autoridades y candidatos de los partidos políticos, según los principios democráticos y sin discriminación por género.

${ }^{32}$ Artículo 35.- Son prerrogativas del ciudadano: I. Votar en las elecciones populares; II. Poder ser votado para todos los cargos de elección popular y nombrado para cualquier otro empleo o comisión, teniendo las calidades que establezca la Ley; III. Asociarse individual y libremente para tomar parte en forma pacífica en los asuntos políticos del país...

Artículo 36.- Son obligaciones del ciudadano de la República: III. Votar en las elecciones populares en los términos que señale la Ley... 
gunos casos, representan buenos ejemplos de configuración muy precisa del sufragio.

Artículo 41: "El pueblo ejerce su soberanía por medio de los Poderes de la Unión, en los casos de la competencia de éstos, y por los de los Estados, en lo que toca a sus regímenes interiores, en los términos respectivamente establecidos por la presente Constitución Federal y las particulares de los Estados, las que en ningún caso podrán contravenir las estipulaciones del Pacto Federal.

La renovación de los poderes Legislativo y Ejecutivo se realizará mediante elecciones libres, auténticas y periódicas, conforme a las siguientes bases:

I. Los partidos políticos son entidades de interés público; la Ley determinará las formas específicas de su intervención en el proceso electoral. Los partidos políticos nacionales tendrán derecho a participar en las elecciones estatales y municipales.

Los partidos políticos tienen como fin promover la participación del pueblo en la vida democrática, contribuir a la integración de la representación nacional y como organizaciones de ciudadanos, hacer posible el acceso de éstos al ejercicio del poder público, de acuerdo con los programas, principios e ideas que postulan y mediante el sufragio universal, libre, secreto y directo. Sólo los ciudadanos podrán afiliarse libre e individualmente a los partidos políticos;

II. La Ley garantizará que los partidos políticos nacionales cuenten de manera equitativa con elementos para llevara cabo sus actividades. Por tanto, tendrán derecho al uso en forma permanente de los medios de comunicación social, de acuerdo con las formas y procedimientos que establezca la misma. Además, la Ley señalará las reglas a que se sujetará el financiamiento de los partidos políticos y sus campañas electorales, debiendo garantizar que los recursos públicos prevalezcan sobre los de origen privado...

III. La organización de las elecciones federales es una función estatal que se realiza a través de un organismo público autónomo denominado Instituto Federal Electoral, dotado de personalidad jurídica y patrimonio propios, en cuya integración participan el Poder Legislativo de la Unión, los partidos políticos nacionales y los ciudadanos, en los términos que ordene la Ley. En el ejercicio de esa función estatal, la certeza, legalidad, independencia, imparcialidad y objetividad serán principios rectores.

El Instituto Federal Electoral será autoridad en la materia, independiente en sus decisiones y funcionamiento y profesional en su desempeño; contará en su estructura con órganos de dirección, ejecutivos, técnicos y de vigilancia. El Consejo General será su órgano superior de dirección y se integrará por un consejero Presidente y ocho consejeros electorales, y concurrirán, con voz pero sin voto, los consejeros del Poder Legislativo, los representantes de los partidos políticos y un Secretario Ejecutivo; la Ley determinará las reglas para la organización y funcionamiento de los órganos, así como las relaciones de mando entre éstos. Los órganos ejecutivos y técnicos dispondrán del personal calificado necesario para prestar el servicio profesional electoral. Las disposiciones de la Ley electoral y del Estatuto que con base en ella apruebe el Consejo General, regirán las relaciones de trabajo de los servidores del organismo público. Los órganos de vigilancia se integrarán mayoritariamente por representantes de los partidos políticos nacionales. Las mesas directivas de casilla estarán integradas por ciudadanos...

IV. Para garantizar los principios de constitucionalidad y legalidad de los actos y resoluciones electorales, se establecerá un sistema de medios de impugnación en los términos que señalen esta Constitución y la Ley. Dicho sistema dará definitividad a las distin- 
En todo caso, la fuerza normativa del derecho fundamental y su pretensión de eficacia inmediata condicionan la posición y la actuación del legislador, que no puede desconocer ni los límites que la Constitución le marca (por ejemplo, no podría fijar una edad para el ejercicio del sufragio superior a la prevista en la norma fundamental) ni ignorar que cuando es llamado a desarrollar el objeto de este derecho lo es con carácter imperativo, para dar efectividad a la norma iusfundamental. En palabras de la Corte Interamericana de Derechos Humanos:

De conformidad con los artículos 23, 24, 1.1 y 2 de la Convención, el Estado tiene la obligación de garantizar el goce de los derechos políticos, lo cual implica que la regulación del ejercicio de dichos derechos y su aplicación sean acordes al principio de igualdad y no discriminación, y debe adoptar las medidas necesarias para garantizar su pleno ejercicio. Dicha obligación de garantizar no se cumple con la sola expedición de normativa que reconozca formalmente dichos derechos, sino requiere que el Estado adopte las medidas necesarias para garantizar su pleno ejercicio, considerando la situación de debilidad o desvalimiento en que se encuentran los integrantes de ciertos sectores o grupos sociales. ${ }^{33}$

El objeto esencial del derecho de voto ya se evidencia antes de que se haya aprobado una ley que lo desarrolle; en este supuesto no actúa como un límite al legislador, ya que éste todavía no ha aprobado la norma, sino que funciona como una fuente constitucional directa de apoderamiento para el titular del derecho, de manera que éste pueda accionar para preservar el ámbito de libertad garantizado.

Esta operatividad se evidencia también cuando el legislador ha actuado, pero con omisiones que lesionan de manera inmediata el objeto del derecho, como declaró, por ejemplo, a propósito del sufragio de los ciegos, la Corte Constitucional de Colombia, ${ }^{34}$ al concluir que:

tas etapas de los procesos electorales y garantizará la protección de los derechos políticos de los ciudadanos de votar, ser votado y de asociación, en los términos del Artículo 99 de esta Constitución. En materia electoral la interposición de los medios de impugnación constitucionales o legales no producirá efectos suspensivos sobre la resolución o el acto impugnado".

${ }^{33}$ Caso Yatama vs. Nicaragua, http://www.corteidh.or.cr/docs/casos/fundamentos/jse riec127.pdf.

${ }^{34}$ Sentencia T-473/03 de 9 de junio de 2003, http://www.ramajudicial.gov.co/csj_por tal/. 
... el aparato estatal debe crear el ambiente propicio en el cual las personas con limitaciones físicas puedan desenvolverse con la dignidad humana que las caracteriza... Las anteriores razones son suficientes para que esta Sala, en la parte resolutiva de esta providencia, ordene a la Registraduria Nacional del Estado Civil, para que con miras a las elecciones futuras implemente el sistema Braile en los tarjetones, de tal manera que se permita ejercer el derecho al sufragio a las personas que necesiten de este medio sin necesidad de estar acompañadas...

En consecuencia, el derecho de voto debe ser desarrollado legislativamente sin que por ese motivo pierda su fundamentalidad, siempre que con dicha regulación infraconstitucional no se disponga de su existencia en el ordenamiento jurídico. Esa es la función del denominado límite del contenido esencial del derecho: que la intervención del legislador siempre sea conforme al contenido abstracto con el que la Constitución ha dotado al derecho de voto, con lo que únicamente cabría imponerle aquellos límites que la propia Constitución reconoce y en los términos que ella prevé. Como ha dicho el Tribunal Europeo de Derechos Humanos: "Ninguna de las condiciones impuestas pueden afectar a la libre expresión del pueblo para la elección del poder legislativo; dicho de otra manera, deben reflejar, y no contravenir, la integridad y efectividad de un procedimiento electoral dirigido a expresar la voluntad popular a través del sufragio universal". 35

Además, con la exigencia del desarrollo legislativo se cumple una de las funciones que corresponden a las reservas de ley en el seno de una Constitución democrática: que sean únicamente los "representantes del pueblo" los que decidan los términos en los que se regulará ese derecho fundamental, de forma que toda intervención del Estado se realice de acuerdo con lo establecido en la norma creada por esos representantes. Así se consagra el "derecho al rango", es decir, el derecho a que el legislador efectúe sus intervenciones en el derecho de voto respetando el rango y procedimiento de elaboración de normas que la Constitución le exige en cada caso; de este modo se realiza la función de garantía del derecho que corresponde a la reserva de ley, sobre la que se volverá al final de estas páginas.

35 Asunto Hirst c. Reino Unido (núm. 2), 6 de octubre de 2005, sentencia del Tribunal Europeo de Derechos Humanos, constituido en Gran Sala, en http://cmiskp.echr.coe.int/. 
El voto constituye un buen ejemplo de un derecho cuyas expectativas de conducta sólo pueden existir y realizarse si media la colaboración de los poderes públicos y, en especial, del Parlamento, pues requiere para su ejercicio el establecimiento de normas de procedimiento y organización. El legislador está llamado a configurar la dimensión subjetiva del derecho fundamental, de forma que ésta sólo podrá ejercerse en los términos previstos en esa norma legal.

Pero, además de la obligación negativa del legislador de no lesionar la esfera individual del derecho de voto, existe también la obligación positiva de contribuir a su efectividad, que adquiere especial relevancia en un derecho que podría quedar vacío de no establecerse los supuestos para su defensa y realización. Es decir, y por utilizar unas palabras ya clásicas del Tribunal Constitucional Federal alemán (BVerfGE 7, 198, [207]), junto a los derechos fundamentales como derechos subjetivos tradicionales frente al poder público, aparecen los derechos fundamentales como normas objetivas que expresan un contenido que se irradia en todos los ámbitos del ordenamiento. ${ }^{36}$

La obligación que se deriva de la dimensión objetiva del derecho fundamental incide en el contenido y el objeto del derecho, e impone a los poderes públicos, por un lado, el deber positivo de protegerlo y, por otro, les obliga a abstenerse de realizar cualquier acto que pueda resultar contrario al citado deber positivo.

De esta dimensión objetiva de la norma que garantiza el derecho de voto se derivan los efectos irradiante y recíproco. Hablamos del efecto irradiante para expresar la necesaria proyección del derecho fundamental como norma de principio en todos los sectores del ordenamiento, con lo que tiene que hacerse notar a la hora de interpretar y aplicar las normas que integran cada una de las ramas (penal, laboral, administrativa...). En lo que respecta al legislador, se manifiesta en la obligación de que tenga bien presente el derecho fundamental en su labor normativa, lo que implica el deber de disciplinarlo de la manera más favorable para su observancia, y como mínimo de forma que no se desconozca su contenido esencial, y por lo que se refiere a los órganos que ejercen funciones jurisdiccionales, la dimensión objetiva del derecho de voto les obliga a que en su labor aplicativa del ordenamiento

${ }^{36}$ http://www.oefre.unibe.ch/law/dfr/bv007198.html y http://www.bverfg.de/entscheidu ngen.html. Nos extendemos sobre la doble dimensión de las normas que garantizan derechos fundamentales en Teoría general de los derechos fundamentales en la Constitución española de 1978..., cit., pp. 50 y ss. 
controlen la adecuación de las normas en presencia de la dimensión objetiva del derecho fundamental. En algunos casos esta tarea conducirá a la declaración de que no existen las disposiciones necesarias, como concluyó el Tribunal de Justicia de las Comunidades Europeas (Sala Sexta) en el asunto Comisión contra Bélgica. ${ }^{37}$

Por su parte, el efecto recíproco se produce entre el derecho de voto y las leyes que disciplinan su ejercicio, generándose un régimen de concurrencia normativa, de manera que tanto las normas que lo regulan como las que establecen límites a su ejercicio actúan recíprocamente $y$, como resultado, la fuerza expansiva propia del derecho fundamental restringe el alcance de las normas limitadoras que actúan sobre el mismo; de ahí deriva la exigencia de que los límites al derecho tengan que ser interpretados con criterios restrictivos y en el sentido más favorable a la esencia y eficacia del mismo.

Es aquí donde adquiere especial relevancia el "principio de proporcionalidad", 38 en virtud del cual los poderes Ejecutivo y Judicial han de utilizar las medidas limitativas del derecho de sufragio que sean idóneas, necesarias y proporcionales en sentido estricto para la consecución de los fines constitucionalmente lícitos predeterminados por la ley. La finalidad del citado principio es evitar que los poderes públicos que tengan atribuida la competencia para aplicar los límites a un derecho fundamental vulneren, al hacerlo, su contenido esencial.

No obstante, parece que respecto del legislador democrático la vigencia del principio de proporcionalidad habrá de tener un sentido diferente en atención al carácter abierto de las normas que integran la norma fundamental. El efecto recíproco, a nuestro juicio, obliga al

37 Este Tribunal declaró que "el Reino de Bélgica ha incumplido las obligaciones que le incumben en virtud del párrafo primero del artículo 14 de la Directiva 94/80/CE del Consejo, de 19 de diciembre de 1994, por la que se fijan las modalidades de ejercicio del derecho de sufragio activo y pasivo en las elecciones municipales por parte de los ciudadanos de la Unión residentes en un Estado miembro del que no sean nacionales, al no adoptar dentro del plazo señalado las disposiciones legales, reglamentarias y administrativas necesarias para atenerse a dicha Directiva"; véase en http://curia.europa.eu/ jurisp/cgi-bin/form.pl?lang=es.

38 Sobre el principio de proporcionalidad, véase el completo estudio de Bernal Pulido, Carlos, El principio de proporcionalidad y los derechos fundamentales: el principio de proporcionalidad como criterio para determinar el contenido de los derechos fundamentales vinculante para el legislador, 2a. ed., Madrid, Centro de Estudios Políticos y Constitucionales, 2005; sobre su control en el ámbito administrativo, Sarmiento, Daniel, El control de proporcionalidad de la actividad administrativa, Valencia, Tirant lo Blanch, 2004. 
legislador a que en su labor limitativa observe el respeto debido a los términos constitucionales que mediatizan su tarea y, en segundo lugar, a que esta última no sea arbitraria o irrazonable, pero no impone que sea "proporcional" en el sentido ya explicado antes de dicho término, pues si así fuera se estaría desposeyendo al legislador de su papel protagonista en la articulación de la política de derechos fundamentales, lo que conduciría a una reducción y no a un refuerzo de su eficacia.

Finalmente, surgen dos preguntas: una sobre el contenido que ha de incluir la legislación electoral y otra acerca de si se necesita una misma ley para los diferentes procesos de ejercicio del derecho de sufragio.

A la primera se puede contestar que para que una ley merezca el calificativo de electoral es necesario que contenga por lo menos el núcleo central de la normativa atinente al proceso de ejercicio del voto, materia en la que se comprende lo relativo a quiénes pueden ejercer el derecho, a quiénes se puede elegir y bajo qué condiciones, para qué espacio de tiempo y con qué criterios organizativos desde el punto de vista procedimental y territorial.

Respecto a la segunda cuestión, relativa a la existencia de una misma ley para todos los procesos electorales, no existe inconveniente teórico para que el desarrollo legislativo del derecho de voto se realice en diferentes bloques normativos: por un lado, la participación en plebiscitos y referendos; el régimen de las elecciones locales en la norma que incluya el sistema de organización y funcionamiento de estas entidades; el sufragio correspondiente a las elecciones legislativas estatales $y$, en su caso, presidenciales, en la norma que establezca el régimen electoral general, y el sufragio que se ejerce en las elecciones a las asambleas legislativas de los entes territoriales con autonomía política en las normas legales aprobadas por estas instituciones. No obstante, que sea posible esta diversidad normativa no significa que sea deseable desde la perspectiva de la seguridad jurídica y de la ordenación sistemática de los procesos electorales. 


\title{
IV. La titularidad del derecho de voto y las abstracciones necesarias para garantizar su carácter universal
}

\begin{abstract}
Un hombre tiene hoy un asno que vale cincuenta dólares yesa posesión le da derecho de voto; sin embargo, el asno muere antes de la siguiente elección; mientras, el hombre adquirió más experiencia, su conocimiento de los principios del gobierno y su comprensión de la humanidad son más amplios, por lo cual está más capacitado para hacer una selección sensata de representantes. Pero el asno ha muerto y el hombre no puede votar. Entonces, caballeros, les suplico que me informen ¿en quién se basaba el derecho al sufragio? ¿En el hombre o en el asno?
\end{abstract}

Benjamín Franklin, en respuesta a una carta de John Adams sobre el derecho de sufragio, 1776

La historia de la humanidad es una historia de repetidos agravios y usurpaciones perpetradas por el hombre contra la mujer, encaminados al objetivo directo de establecer una tiranía absoluta sobre ella. Él jamás ha permitido que ella ejerza su derecho inalienable de votar en las elecciones. Él la ha obligado a someterse a leyes en cuya formulación ella no tuvo derecho de opinar. Al privarla de este derecho al sufragio, el primer derecho de todo ciudadano, la ha dejado sin representación alguna en los recintos de la legislación. Él la ha oprimido en todos los aspectos.

Declaración de la Convención de Seneca Falls, $1848^{39}$

Como ya se ha dicho, el carácter democrático de un sistema jurídico tiene como premisa lógica que la intervención de los individuos en el ejercicio del poder no se reduzca a una función legitimadora de las limitaciones impuestas por el legislador a la libertad de las personas, sino que garantice la participación de los destinatarios de las decisiones políticas y de las normas en su proceso de elaboración. Esta posibilidad de intervenir se le reconoce a la persona como un derecho y, en consecuencia, deberían poder participar todos los sometidos de manera continuada a un determinado ordenamiento, si bien puede ocurrir que dicho sistema jurídico no realice una abstracción total de las circuns-

${ }^{39}$ http://clio.rediris.es/udidactica/sufragismo2/inicfemusa.htm. 
tancias personales de los individuos y requiera la concurrencia de una serie de requisitos, siempre que con estas exigencias no menoscabe la esencial abstracción de las condiciones sociales, culturales y económicas que ha de presidir el reconocimiento del voto como un derecho de todos.

Antes de continuar es necesaria una precisión, aunque sea breve, sobre la titularidad de los derechos fundamentales y las opciones que se presentan al constituyente a la hora de establecer los principios rectores en esta materia.

En el momento de determinar en quién puede recaer la titularidad de un derecho fundamental suelen plantearse cuatro grandes opciones: si es necesaria la personalidad para ser titular del derecho; si son titulares únicamente las personas físicas o si pueden serlo además las jurídicas; si se exige, o no, la mayoría de edad y, por último, si se reduce el ámbito de los titulares a los nacionales o si puede extenderse a los extranjeros. ${ }^{40}$

Sobre la primera cuestión, debe recordarse que en la mayoría de los ordenamientos vigentes el nasciturus no es titular de derechos fundamentales, aunque sí suele gozar de la condición de bien constitucionalmente protegido; ${ }^{41}$ en suma, la titularidad plena de los derechos fundamentales se atribuye a las personas nacidas.

Despejada esta primera alternativa, surge una duda referida al reconocimiento exclusivo de los derechos a las personas físicas o a la

40 Véase, sobre esta cuestión, Bastida et al., Teoría general de los derechos fundamentales en la Constitución Española de 1978..., cit., pp. 83 y ss.

${ }^{41}$ La sentencia del Tribunal Europeo de Derechos Humanos del 8 de julio de 2004 en el asunto Vo c. Francia, reconoce la protección del feto sin necesidad de considerarlo una persona con derecho a la vida a los efectos del artículo 2o. del Convenio; el Tribunal señala también que, este artículo, de manera diferente a lo que sucede con el artículo 4o. de la Convención Americana de Derechos Humanos, no extiende la protección de la vida al momento de la concepción; la sentencia del Tribunal Europeo está disponible en http://cmiskp.echr.coe.int/.

Nos hemos ocupado de esta cuestión en el estudio El derecho europeo de familia, Thomson/Aranzadi, Cizur Menor, 2008, pp. 97 y ss.; sobre el distinto tratamiento en el Convenio Europeo de Derechos Humanos y en la Convención Americana de Derechos Humanos véanse, respectivamente, las contribuciones de Laurence Burgorgue-Larsen, "El derecho a la vida y la dignidad personal: una aproximación de la Corte Europeo de los Derechos Humanos", y Antonio Moreira Maués, "O direito à vida na jursprudência da Corte Interamericana de Direitos Humanos”, ambos en Revenga, Miguel y Viana, André (eds.), Tendencias jurisprudenciales de la Corte Interamericana y del Tribunal Europeo de Derechos Humanos, Valencia, Tirant, 2008, pp. 72 y ss., 93 y ss. 
posibilidad de extenderlo a las personas jurídicas. Con carácter general, no se puede negar a las personas jurídicas de derecho privado la titularidad de aquellos derechos fundamentales que, por su naturaleza, sean susceptibles de ser ejercitados por ellas, como, por ejemplo la inviolabilidad de domicilio o el derecho al honor. Dicho lo anterior, parece claro que en el caso del voto no nos encontramos ante un derecho fundamental cuya titularidad pueda ser reconocida a una persona jurídica privada, por ejemplo, a un partido, ${ }^{42}$ lo que no impide atribuir a estas entidades un papel muy relevante en los procesos electorales $y$, en general, dentro del sistema democrático, como hacen, por mencionar algún ejemplo, la Constitución mexicana (artículo 41: "Los partidos políticos tienen como fin promover la participación del pueblo en la vida democrática, contribuir a la integración de la representación nacional y como organizaciones de ciudadanos, hacer posible el acceso de éstos al ejercicio del poder público, de acuerdo con los programas, principios e ideas que postulan y mediante el sufragio universal, libre, secreto y directo..."), y la Española (artículo 6o.: "Los partidos políticos expresan el pluralismo político, concurren a la formación y manifestación de la voluntad popular y son instrumento fundamental para la participación política...”).

Por lo que a las personas físicas se refiere, en principio, la titularidad de los derechos fundamentales se reconoce en la mayoría de los casos a todas, a todos los seres humanos, sin distinción entre mayores y menores de edad, capaces o incapaces, ni entre nacionales y extranjeros. Es lo que sucede cuando en los textos constitucionales se emplean los sujetos "todos", las "personas", "nadie"..., o cuando se emplean términos impersonales ("se garantiza", "se reconoce”...).

En el caso de los menores o incapaces su condición personal no les inhabilita para ser titulares de los derechos respectivos, pues no por ello dejan de ser "personas", "nacionales", "extranjeros"...; lo que sucede es que el ejercicio de los derechos no siempre pueden llevarlo a cabo por sí mismos y, en ocasiones, como ocurre precisamente con el voto, como veremos de inmediato, o con cualquier otro derecho "personalísimo", no pueden ejercerlo ni siquiera con el auxilio de sus padres,

42 Nos ocupamos de esta cuestión en España en Los partidos políticos en el sistema constitucional español. Prontuario de jurisprudencia constitucional 1980-1999, Pamplona, Aranzadi, 2000. 
tutores, etcétera, ${ }^{43}$ aunque esta última posibilidad sí es admitida por un sector de la doctrina alemana. ${ }^{44}$

Si la participación política a través del voto es consustancial a la democracia, su configuración ha de estar presidida por la idea de que todos los que son titulares de esa participación han ser, por consiguiente, titulares del derecho. En la mayoría de los ordenamientos constitucionales la participación en la vida política se atribuye a "todos los ciudadanos", ${ }^{45}$ por lo que "todos" tendrían que ser titulares del derecho de sufragio. En ese "todos" se incluirían menores y mayores, capaces e incapaces, pero que todos sean titulares del derecho no significa que todos pueden ejercer una de sus facultades, quizá la más relevante, votar, pues sólo son "electores", sólo pueden emitir el sufragio, "los que estén en pleno uso de sus derechos políticos".

En realidad esta última declaración es redundante: la participación es un derecho político, por lo que pueden "usarlo", ejercerlo, los que no estén privados del ejercicio de ese derecho. Pero incluso los que no pueden votar sí pueden ejercer parte del objeto del derecho, dado que tienen la posibilidad de llevar a cabo las acciones necesarias para garantizar en su momento la emisión del voto. Esto es lo que sucede, por citar un caso, en la Ley Orgánica del Régimen Electoral General española cuando, a propósito de la formación y actualización del censo o padrón electoral, dispone que "en la actualización correspondiente al primer mes del año se acompañarán además, en los términos previstos en el párrafo anterior, las altas, con la calificación de menor, de los

${ }^{43}$ Sobre los derechos fundamentales de los menores y su capacidad para ejercerlos, véase dentro del libro de Albert Bleckmann, Staatsrecht II-Die Grundrechte (3., um die Besonderen Grundrechtslehren erweiterte Auflage), Múnich, Carl Heymanns Verlag, 1989 , la parte relativa a la capacidad de obrar en materia de derechos fundamentales (“Die Grundrechtsmündigkeit”), pp. 417 y ss. En la doctrina de habla española es de referencia obligada el estudio de Aláez Corral, Benito, Minoría de edad y derechos fundamentales, Madrid, Tecnos, 2003.

${ }_{44}$ Resultan interesantes, en particular a propósito del sufragio de los menores a través de sus padres, las propuestas formuladas por Konrad Löw en su trabajo "Das selbsverständnis des Grundgesetzes und wirklich allgemeine Wahlen”, Politische Studien, núm. 25, 1974, pp. 18 y ss.; sobre esta última cuestión, véase también, en la doctrina norteamericana, el trabajo de Robert W. Bennet, "Should Parents be Given Extra Votes on Account of Their Children?: Toward a Conversational Understanding of American Democracy", Northwestern University Law Review, vol. 94, núm. 2, pp. 503 y ss.

45 Así, artículo 40 de la Constitución colombiana; 9.2 de la Española; enmienda XV de la estadounidense; artículo 35 de la mexicana; 129 de la panameña; 31 de la peruana; 77 de la uruguaya; 62 de la venezolana. 
residentes que cumplirán dieciocho años entre el 1 de enero y el 31 de diciembre del año siguiente" (artículo 35.2). ${ }^{46}$

No nos extenderemos más en este momento, pues en las páginas siguientes se analizarán de manera pormenorizada los diferentes problemas que se plantean en materia de titularidad (nacionales y/o extranjeros) y ejercicio (menores, presos, militares, policías) del derecho fundamental de sufragio.

Cabe recordar ahora que la universalización de los derechos de participación política suele constituir la última fase, después de los derechos de libertad y de los de carácter social, en la evolución del reconocimiento de los derechos fundamentales en el seno de un ordenamiento jurídico determinado. Esta aproximación del pueblo gobernado al pueblo que gobierna, de la sociedad al Estado, se desenvuelve a lo largo de un proceso histórico caracterizado por una serie de abstracciones: la propiedad, la raza, el sexo y la exigencia de una edad cada vez menor. En algunos ordenamientos esta evolución ha alcanzado a la condición de nacional, al considerar como integrante del pueblo gobernado que ha de actuar como gobernante a todo aquel que, dotado de capacidad para participar en la formación de comunicaciones políticas relativas al autogobierno de una comunidad, se somete con cierta continuidad temporal a un determinado ordenamiento.

La atribución de carácter universal al sufragio tanto en los textos constitucionales como en los tratados internacionales significa que en la articulación de los procesos electorales se prescindirá de cualquier circunstancia personal, social, cultural, económica o política, para delimitar la condición de titular del sufragio. Es evidente, como se constatará de inmediato, que esta abstracción no es absoluta, al menos en lo que hace referencia a una de las concreciones del derecho de voto: su emisión, puesto que no pueden votar todas las personas; no pueden hacerlo los menores ni los incapaces, ni tampoco, en numerosos ordenamientos o en algunos procesos electorales, los extranjeros.

Alguna de las restricciones a la emisión del voto podría ser eliminada a objeto de dotarlo de "más" democracia, lo que supondría al

${ }^{46}$ Lo mismo ocurre con los mayores de edad que no pueden votar por incapacitación o internamiento en un hospital psiquiátrico: "Los encargados del Registro Civil y del Registro de Penados y Rebeldes comunicarán a las Delegaciones Provinciales de las Oficinas del Censo Electoral, mensualmente y dentro de los plazos fijados por la Oficina del Censo Electoral, cualquier circunstancia, de orden civil o penal, que pueda afectar a la inscripción en el censo electoral, referida al mes anterior” (artículo 37). 
tiempo una mejora cuantitativa y cualitativa del sistema político al lograr una mayor aproximación del pueblo gobernado al pueblo gobernante. En esta línea se inscribirían las reformas, legales algunas y constitucionales otras, destinadas en su caso a rebajar la edad mínima para poder votar, y a reconocer el derecho de sufragio a los residentes en el territorio, sean nacionales o extranjeros. Sobre estas cuestiones nos extenderemos en las próximas páginas.

No obstante, es necesario recordar en pocas palabras uno de sus hitos históricos: el que supuso la incorporación de un colectivo que representa en la práctica la mitad, o más, de la población y que permanecía excluido del sufragio: las mujeres. Esta ampliación se enmarca en un proceso de reconocimiento de las funciones que las mujeres pueden desempeñar en el seno de la sociedad; por decirlo en las palabras escritas en 1903 por Adolfo Posada, que fue el primero que se ocupó en España de estudiar desde una perspectiva doctrinal la conveniencia de ampliar el voto a las mujeres, esta cuestión se inserta en "el carácter de palpitante actualidad que tiene el llamado movimiento feminista, es decir, el movimiento encaminado a mejorar y levantar la condición moral, social y jurídica de las mujeres, y el cual precisamente formula, entre una de sus más acariciadas reivindicaciones, el sufragio femenino" ${ }^{47}$

Este autor, además de exponer la situación del sufragio femenino en los lugares en los que ya había sido reconocido (por ejemplo, en Nueva Zelanda - 1893 - o en los estados norteamericanos de Wyoming -1889-, Colorado - 1893 - o Utah -1895-), se pronuncia de manera rotunda al respecto. ${ }^{48}$

47 Cfr. El sufragio según las teorías filosóficas y las principales legislaciones, Barcelona, Sucesores de Manuel Soler, 1903, p. 107.

${ }^{48}$ De acuerdo con el artículo 7o. de la Sección 1a. de la Constitución de este Wyoming, de 1899, "los derechos de los ciudadanos del Estado de Wyoming a votar y a desempeñar cargos no serán negados ni restringidos a causa del sexo. Los ciudadanos de este Estado, sean varones o mujeres gozarán igualmente de todos los derechos y prerrogativas civiles, políticas y religiosas". En la Sección 2a se declara que "todo ciudadano de los Estados Unidos, de veintiún años en adelante, que resida en el Estado o territorio durante un año, y en el condado en que tal residencia conste, sesenta días antes de la elección, podrá votar en la elección misma, salvo cuando aquí se dispusiera otra cosa".

- Sobre este proceso en Estados Unidos, véase Keyssar, Alessander, The Rigth to vote. The contested history of democracy in the United States, Nueva York, Basic Books, 2000, pp. 172 y ss. Suele situarse el origen de la reivindicación del sufragio para la mujer en la Convención de Seneca Falls de 1848, que copió gran parte de la Declaración de Indepen- 
Estas consideraciones no se quedaban en el plano doctrinal sino que encontraron traducción jurídica en diversos ordenamientos, aunque su extensión se retrasó hasta los últimos años de la segunda década del siglo XX (Constitución de los Estados Unidos Mexicanos, de $1917 ;{ }^{49}$ Constitución del Reich alemán, de $1919 ;{ }^{50}$ Enmienda Diecinueve a la Constitución de los Estados Unidos, de 191951) y primeros años de la década de los treinta (Constitución Española de 1931). ${ }^{52}$ No deja de resultar sorprendente que el reconocimiento del sufragio femenino se retrase en Francia hasta 1945 y en Suiza hasta 1971.

Con posterioridad a la Segunda Guerra Mundial, además de la incorporación a los textos constitucionales de casi todos los Estados del derecho de los nacionales a participar en los asuntos públicos sin exclusión alguna por razón de sexo, el sufragio activo femenino aparece reconocido en los tratados internacionales relativos a los derechos de las personas ${ }^{53} \mathrm{y}$, en la actualidad, se da por existente. Está en proceso

dencia y luego insertó en ella los "pecados del hombre contra la mujer", en sustitución de los agravios de Jorge III contra sus colonias de Norteamérica; puede leerse en http://clio. rediris.es/udidactica/sufragismo2/inicfemusa.htm.

- “Es que la mujer — en general- no tiene el minimun de capacidad intelectual y moral que para el ejercicio del sufragio se exige en el hombre, sea cual fuere el criterio con arreglo al cual se concede o reconoce el sufragio?... ¿Es que acaso la mujer no tiene el mismo interés que el hombre en la vida del derecho y del Estado?... En verdad, miradas las cosas desde este punto de vista, el problema apenas permite discusión. Aquel principio que formulábamos, y según el cual, siendo el sufragio una función, una vez determinada la capacidad que su desempeño exige, no hay derecho (sic) a excluir a nadie que tenga aquella capacidad, parece que pide ser interpretado en favor de la mujer". Posada parte de la consideración del sufragio no como un derecho sino como una función, con lo que el elector es un funcionario, llamado por el derecho positivo, que deberá tener en cuenta la capacidad de los individuos para la función que han de realizar; véase al respecto el estudio preliminar del profesor Rubio Llorente a los Estudios sobre el Régimen Parlamentario en España, en la Colección "Clásicos Asturianos del Pensamiento Político”, núm. 8, Junta General del Principado de Asturias, Oviedo, 1996, pp. LXXVI y ss.

49 "Son prerrogativas del ciudadano: 1. Votar en las elecciones populares..." (artículo 35).

50 "Los diputados serán elegidos mediante sufragio universal, igual, directo y secreto, y con arreglo a los principios de representación proporcional, por los hombres y mujeres de más de veinte años..." (artículo 22).

51 “Ni los Estados Unidos ni ningún Estado podrán negar o coartar, por razón de sexo, el derecho al sufragio de los ciudadanos de los Estados Unidos".

${ }^{52}$ El artículo 36 establecía que "los ciudadanos de uno y otro sexo, mayores de veintitrés años, tendrán los mismos derechos electorales conforme determinen las leyes".

53 Así, por ejemplo, el artículo 25 del Pacto Internacional de Derechos Civiles y Políticos, hecho en Nueva York el 19 de diciembre de 1966, dispone que “Todos los ciudada- 
de expansión, y los ordenamientos iberoamericanos son buena prueba de ello, ${ }^{54}$ la implantación de sistemas de cuotas para asegurar una presencia mínima de mujeres en los cargos representativos, pero dado que se trata de una cuestión relativa al sufragio pasivo no nos ocuparemos aquí de este asunto.

nos gozarán, sin ninguna de las distinciones mencionadas en el artículo $2^{\circ}$ [raza, sexo, idioma,...] y sin restricciones indebidas, de lo siguientes derechos y oportunidades: a) participar en la dirección de los asuntos públicos, directamente o por medio de representantes libremente elegidos; b) votar y ser elegidos en elecciones periódicas, auténticas, realizadas por sufragio universal e igual y por voto secreto que garantice la libre expresión de la voluntad de los electores...”.

54 Véase el estudio de León, Magdalena (ed.), Nadando contra corriente. Mujeres y cuotas políticas en los países andinos, Bogotá, UNIFEM-UNFPA-Universidad Nacional de Colombia-IEP-Flacso, 2005.

En España, la Ley Orgánica 3/2007, del 22 de marzo, para la igualdad efectiva de hombres y mujeres obliga a una composición equilibrada de hombres y mujeres en las listas electorales, de modo que las personas de cada sexo no superen el $60 \%$ ni sean menos del 40\%: "Artículo 44 bis. 1. Las candidaturas que se presenten para las elecciones de diputados al Congreso, municipales y de miembros de los consejos insulares y de los cabildos insulares canarios en los términos previstos en esta Ley, diputados al Parlamento Europeo y miembros de las Asambleas Legislativas de las Comunidades Autónomas deberán tener una composición equilibrada de mujeres y hombres, de forma que en el conjunto de la lista los candidatos de cada uno de los sexos supongan como mínimo el cuarenta por ciento. Cuando el número de puestos a cubrir sea inferior a cinco, la proporción de mujeres y hombres será lo más cercana posible al equilibrio numérico... 2 . También se mantendrá la proporción mínima del cuarenta por ciento en cada tramo de cinco puestos. Cuando el último tramo de la lista no alcance los cinco puestos, la referida proporción de mujeres y hombres en ese tramo será lo más cercana posible al equilibrio numérico, aunque deberá mantenerse en cualquier caso la proporción exigible respecto del conjunto de la lista... 3. A las listas de suplentes se aplicarán las reglas contenidas en los anteriores apartados”. 


\title{
V. La condena penal no debe suspender la ciudadanía: los presos también son importantes
}

\author{
El voto de cada ciudadano es un símbolo de dignidad e \\ identidad individual. Literalmente, significa que todo \\ el mundo es importante ${ }^{55}$ \\ Privar a los presos del derecho de voto nos haría \\ retroceder y restringiría nuestros derechos \\ democráticos ${ }^{56}$
}

En general suele creerse que la historia del derecho de sufragio consiste en una constante e imparable extensión, pero lo cierto es que está jalonada de avances y retrocesos, de inclusiones y exclusiones, y la situación de los presos es un buen ejemplo. En este momento se puede afirmar que en algunos países, como Estados Unidos, los presos constituyen el grupo más numeroso de ciudadanos que, reuniendo los requisitos para ser titulares del sufragio (nacionalidad, mayoría de edad, capacidad de discernimiento), están privados de su ejercicio, estimándose que en las elecciones presidenciales de 2008 esta exclusión pudo afectar a más de cinco millones de personas. ${ }^{57}$ En ese país, todos los estados, salvo Maine, Massachusetts, Utah y Vermont, tienen previsiones legales que excluyen a los presos y, en algunos casos, a las personas en libertad condicional; en diez estados la exclusión del derecho se extiende de por vida, aunque la persona ya hubiera extinguido su condena.

En una importante sentencia del Tribunal Europeo de Derechos $\mathrm{Hu}-$ manos - Hirst c. Reino Unido (núm. 2), del 6 de octubre de 2005-58 este órgano, constituido en Gran Sala, incluyó en la relación de hechos que preceden a la fundamentación jurídica un estudio sobre el derecho de voto de los presos, realizado por el gobierno demandado

55 Tribunal Supremo de Sudáfrica, August c. Electoral Commission, 1o. de abril de 1999. http://www.constitutionalcourt.org.za/site/home.htm; http://www.saflii.org/za/case s/ZACC/1999/3.pdf.

56 Tribunal Supremo de Canadá, Sauvé c. Canada (Chief Electoral Officer), 31 de octubre de 2002, http://scc.lexum.umontreal.ca/fr/2002/2002csc68/2002csc68.html; http:// scc.lexum.umontreal.ca/en/2002/2002scc68/2002scc68.html.

57 Véase el informe para el Brennan Center for Justice de Erika Word y Rachel Blomm: De Facto Disenfranchisement, disponible en http://brennan.3cdn.net/578d11c906d81d54 $8 f \_1$ tm6iiqab.pdf.

58 Puede consultarse a través de la página del Tribunal: http://cmiskp.echr.coe.int/. 
a partir de las informaciones aportadas por sus representaciones diplomáticas.

Según dicho estudio, en dieciocho países (Albania, Alemania, Azerbaiyán, Croacia, Dinamarca, Macedonia, Finlandia, Islandia, Lituania, Moldavia, Montenegro, Países Bajos, Portugal, República Checa, Eslovenia, Suecia, Suiza, Ucrania) los presos están autorizados a votar sin ninguna restricción; en trece países (Armenia, Bélgica, ${ }^{59}$ Bulgaria, Chipre, Estonia, Georgia, Hungría, Irlanda, Reino Unido, Rusia, Serbia, Eslovaquia, ${ }^{60}$ Turquía) todos los presos están condenados a la prohibición de votar o están imposibilitados para hacerlo, y en once países (Austria, ${ }^{61}$ Bosnia-Herzegovina, ${ }^{62}$ España, ${ }^{63}$ Francia, ${ }^{64}$ Grecia,${ }^{65}$ Italia, ${ }^{66}$ Luxemburgo ${ }^{67}$ Malta,${ }^{68}$ Noruega ${ }^{69}$ Polonia, ${ }^{70}$ Rumania) el derecho de voto de los presos puede estar limitado de alguna manera. El Tribunal afirma, por su parte, que en Rumania, los presos pueden estar privados del voto si la pena principal es superior a dos años de prisión; en Letonia los presos que cumplan su pena en una peniten-

59 La privación del derecho de voto puede prolongarse hasta el fin de la reclusión.

${ }^{60}$ No hay prohibición pero nada permite a los presos votar.

${ }_{61}$ El derecho de voto se prohíbe a los presos condenados a una pena de más de un año que hayan obrado de manera intencionada.

62 Las restricciones al derecho de voto se aplican a los presos acusados de graves violaciones del derecho internacional o inculpados por un tribunal internacional.

${ }^{63}$ Aunque no es lo que se dice en el informe citado, con el Código Penal de 1995 ha desaparecido la pena de privación del derecho de sufragio activo.

${ }_{64}$ Los presos pueden votar si el tribunal les concede el derecho.

${ }^{65}$ Las restricciones se aplican a los presos condenados a penas superiores a diez años; los condenados a cadena perpetua son privados definitivamente del derecho de voto. Para las penas comprendidas entre un año y diez, los tribunales pueden limitar el derecho de voto por un periodo de uno a cinco años si el comportamiento demuestra perversidad moral.

${ }^{66}$ Los autores de delitos graves y los quebrados condenados a una pena de cinco años o más pierden automáticamente el derecho de voto, mientras que los autores de infracciones menores excluidos de la función pública pierden, o no, el derecho de voto según la decisión del juez.

${ }^{67}$ Salvo si la supresión de derechos políticos forma parte de la pena impuesta por el juez.

68 Los condenados por una infracción grave pierden el derecho de voto.

${ }^{69}$ El derecho de voto puede ser suprimido por un tribunal, aunque sea muy raro y puede limitarse a los casos de traición y de atentado a la seguridad nacional.

${ }^{70}$ Los presos condenados a una pena de tres años o más cuando la infracción es "reprochable" (muy grave) pueden ser privados del derecho de voto. 
ciaría no tienen derecho de voto; en Liechtenstein los presos no tienen derecho de voto.

En este ámbito jurídico es de aplicación el artículo 3o. del Protocolo núm. 1 del Convenio Europeo de Derechos Humanos: "Las Altas Partes Contratantes se comprometen a organizar, a intervalos razonables, elecciones libres con escrutinio secreto, en condiciones que garanticen la libre expresión de la opinión del pueblo en la elección del cuerpo legislativo". ${ }^{71}$

Con carácter más general, las disposiciones pertinentes del Pacto Internacional de Derechos Civiles y Políticos proclaman (artículo 25) que:

Todos los ciudadanos gozarán, sin ninguna de las distinciones mencionadas en el artículo 2 [raza, color, sexo, idioma, religión, opinión política o de otro tipo, origen nacional o social, posición económica, nacimiento o cualquier otra circunstancia], y sin restricciones indebidas, de los siguientes derechos y oportunidades: a) Participar en la dirección de los asuntos públicos, directamente o por medio de representantes libremente elegidos; b) Votar y ser elegidos en elección periódicas, auténticas, realizadas por sufragio universal e igual y por voto secreto que garantice la libre expresión de la voluntad de los electores...

Previamente se dice (artículo 10) que:

1. Toda persona privada de libertad será tratada humanamente y con el respeto debido a la dignidad inherente al ser humano... 3. El régimen penitenciario consistirá en un tratamiento cuya finalidad esencial será la reforma y la readaptación social de los penados. Los menores delincuen-

${ }^{71}$ Para una panorámica de la jurisprudencia del Tribunal Europeo de Derechos Humanos en materia de elecciones véanse el estudio de Pinelli, Cesare, "Diritto a liberi elezioni", en Bartole et al. (coords.), Comentario a la Convenzione Europea per la tutela dei diritti dell'uomo e delle libertà fondamentali, Padua, Cedam, 2001, pp. 845-961; la síntesis de García Roca, Javier, "Del compromiso internacional de los Estados de organizar elecciones libres al derecho de sufragio de los ciudadanos (artículo 3 P1 CEDH)”, en García Roca, Javier y Santolaya, Pablo (coords.), La Europa de los derechos. El Convenio Europeo de Derechos Humano, Madrid, Centro de Estudios Políticos y Constitucionales, 2005, pp. 825 y ss., así como nuestro comentario al derecho de voto en Sarmiento et al., Las sentencias básicas del Tribunal Europeo de Derechos Humanos. Estudio y jurisprudencia, Madrid, Thomson-Civitas, 2007, pp. 140 y ss. 
tes estarán separados de los adultos y serán sometidos a un tratamiento adecuado a su edad y condición jurídica.

En la observación general núm. 25 (57) adoptada el 12 de julio de 1996, el Comité de Derechos Humanos de Naciones Unidas declaró respecto del derecho garantizado por el artículo 25:

14. En sus informes, los Estados parte deben precisar los motivos de la privación del derecho de voto y justificarlos. Estos motivos deben ser objetivos y razonables. Si el hecho de haber sido condenado por una infracción es un motivo de privación del derecho de voto, el período durante el que aquella interdicción se aplica debe estar en relación con la infracción y la sentencia. Las personas privadas de libertad no deberían, por ese mero hecho ser desposeídas del derecho de voto.

Por su parte, el artículo 23 de la Convención Americana de Derechos Humanos - Pacto de San José- señala al respecto:

Derechos Políticos. 1. Todos los ciudadanos deben gozar de los siguientes derechos y oportunidades: a) de participar en la dirección de los asuntos públicos, directamente o por medio de representantes libremente elegidos; b) de votar y ser elegidos en elecciones periódicas auténticas, realizadas por sufragio universal e igual y por voto secreto que garantice la libre expresión de la voluntad de los electores, y c) de tener acceso, en condiciones generales de igualdad, a las funciones públicas de su país. 2. La ley puede reglamentar el ejercicio de los derechos y oportunidades a que se refiere el inciso anterior, exclusivamente por razones de edad, nacionalidad, residencia, idioma, instrucción, capacidad civil o mental, o condena, por juez competente, en proceso penal (énfasis añadido). ${ }^{72}$

La apertura de los textos internacionales y, en numerosos casos, de las propias Constituciones de los Estados ha originado soluciones diversas sobre el estatuto político de los presos y detenidos, ámbito sobre el que también se han venido pronunciando instancias jurisdic-

72 La cita jurisprudencial obligada sobre la interpretación de este artículo es el asunto, varias veces citado, Yutama vs. Nicaragua, que reproducimos en la segunda parte de este libro. Respecto al sufragio pasivo véase el caso Castañeda Gutman, del 6 de agosto de 2008, disponible en $h t t p: / / w w w . c o r t e i d h . o r . c r / d o c s / c a s o s / a r t i c u l o s / s e r i e c \_184 \_e s p . d o c$. 
cionales internacionales (Tribunal Europeo de Derechos Humanos) ${ }^{73}$ y nacionales (Tribunal Supremo de Estados Unidos, ${ }^{74}$ Tribunal Supremo de Canadá, ${ }^{75}$ Tribunal Supremo de Sudáfrica, ${ }^{76}$ Corte Constitucional de Colombia ${ }^{77}$ Corte Suprema de Justicia de Argentina, ${ }^{78}$ Sala Superior del Tribunal Electoral de México, ${ }^{79}$ Tribunal Superior Electoral de Brasi ${ }^{80}$ ).

Esta cuestión es un buen ejemplo de "diálogo de jurisdicciones" entre culturas jurídicas bien distintas, aunque las respuestas no sean coincidentes. Al respecto, y por citar un ejemplo, la Sala Superior del Tribunal Electoral de México al pronunciarse sobre un problema relacionado con el sufragio de los presos hace un excursus por las respuestas ofrecidas en otras latitudes:

Así, por ejemplo, el Tribunal Europeo de Derechos Humanos en el caso Hirst $v s$. Reino Unido estimó que extender la suspensión del derecho al sufragio de forma abstracta, general e indiscriminada era incompatible con las obligaciones derivadas del derecho internacional de los derechos humanos, particularmente del Convenio Europeo en la materia. Lo anterior, entre otras razones porque no existe una liga entre la suspensión de los derechos políticos y la supresión de la criminalidad, siendo que la supresión del derecho al sufragio podría, de manera colateral, actuar contrariamente a la readaptación social del individuo. En sentido similar se ha pronunciado el Comité de Derechos Humanos de Naciones Unidas al señalar que la limitación injustificada del ejercicio del derecho al sufra-

${ }^{73}$ Hirst c. Reino Unido, primero el 30 de marzo de 2004 y luego el 6 de octubre de 2005; http://cmiskp.echr.coe.int/.

${ }^{74}$ Richardson v. Ramirez, 418 U.S. 24 (1974); http://www.justia.us/us/418/24/case.html.

75 Sauvé c. Canadá (núm. 2), del 31 de octubre de 2002; http://scc.lexum.umon treal.ca/fr/2002/2002csc68/2002csc68.html;http://scc.lexum.umontreal.ca/en/ 2002/2002scc68/2002scc68.html.

${ }^{76}$ August and another v Electoral Commission and others, de 1 de abril de 1999, disponible en $h t t p: / / w w w . c o n s t i t u t i o n a l c o u r t . o r g . z a / s i t e / h o m e . h t m$ y http://www.saflii.org/ za/cases/ZACC/1999/3.pdf, y Minister of Home Affairs v. National Institute for Crime Prevention and Re-Integration of Offenders (Nicro) and others, del 3 de marzo de 2004, http:// www.constitutionalcourt.org.za/site/home.htm.

77 Sentencia 329/03, del 29 de abril de 2003; en http://www.ramajudicial.gov.co/csj_ portal/.

${ }^{78}$ Sentencias del 27 de septiembre de 2001 y 9 de abril de 2002, en http://www.csjn. gov.ar/.

79 Sentencia del 28 de febrero de 2007, http://www.trife.gob. $m x /$.

${ }^{80}$ Resoluciones 20.471, del 14 de septiembre de 1999; 21.160, del 1o. de agosto de 2002, y 21.804, del 8 de junio de 2004, en http://www.tse.gov.br. 
gio a los condenados constituye una sanción adicional que no contribuye a la rehabilitación social del detenido... En el mismo sentido, la Suprema Corte de Canadá en el caso Sauvé v. Canada (Chief Electoral Officer), estimó que la autoridad electoral había omitido identificar aspectos particulares que justificaran la negación del derecho de voto, a ciudadanos que se encontraban encarcelados. Dicho de otro forma, "la autoridad no ofreció ninguna teoría creíble que justificara por qué la denegación de un derecho fundamental democrático puede ser considerado como una forma de pena estatal"... La Suprema Corte de Israel discutía en 1996 la suspensión de los derechos de ciudadanía de Yigal Amir, quien fuera el asesino del Primer Ministro Yitzak Rabin, para finalmente favorecer al ciudadano. Igualmente, el Tribunal Constitucional de Sudáfrica, en 1999 se pronunció por el carácter universal de los derechos políticos como aspecto fundamental en términos de civilidad y de democracia8 En el mismo sentido otros países han limitado la restricción del derecho de sufragio a favor de los condenados entre ellos, Japón, Perú, Noruega, Polonia, Kenya, Dinamarca, Republica Checa, Rumania, Zimbabwe, Holanda, Suecia, Francia y Alemania... ${ }^{81}$

Como se puede constatar, a la vista de esta panorámica legal y jurisprudencial, el abanico de respuestas jurídicas a los derechos políticos de los presos es muy variado. Con carácter general, en los ordenamientos que privan a estas personas del derecho de sufragio nos encontramos ante una restricción dirigida contra ellas por encontrarse en esa concreta relación jurídica de sujeción especial; se trata, en suma, de la privación de garantía constitucional al comportamiento consistente en la emisión del sufragio en razón del sujeto que lo podría llevar a cabo y que gozaría de plena protección jurídica si fuese realizado por personas que no se encontraran inmersas en la citada relación de sujeción especial. No obstante, como ya se ha apuntado al inicio de este epígrafe, existen todavía en Estados Unidos diez legislaciones estatales que extienden la privación del sufragio a los ex reclusos y lo hacen con carácter vitalicio.

Este límite puede estar previsto por la propia Constitución, de manera similar a lo que ocurre, como ya hemos visto, con los menores o, como veremos de inmediato, con los extranjeros. Así, por citar algunos casos, se suspende el ejercicio del derecho de sufragio a los presos

${ }^{81}$ Sentencia del 28 de febrero de 2007, http://www.trife.gob.mx/. 
en el artículo 15 de la Constitución brasileña, y el 16 de la chilena (basta el mero procesamiento).

En Estados Unidos, el Tribunal Supremo ha avalado la capacidad de los Estados para privar a los presos del sufragio, amparándose en la dicción de la Enmienda XIV, donde se excluye por "participar en rebelión o en otro delito". ${ }^{82}$ En México, el artículo 38, fracción II, de la Constitución ordena la suspensión de los derechos ciudadanos a quienes se encuentran sujetos a un proceso criminal desde la fecha del llamado "auto de formal prisión" que es una resolución judicial que se dicta al inicio del proceso y, por lo mismo, antes de que se determine la culpabilidad o inocencia del procesado, ${ }^{83}$ si bien la jurisprudencia de la Sala Superior del Tribunal Electoral no ha sido congruente con ese mandato constitucional. ${ }^{84}$

${ }^{82}$ Richardson v. Ramirez, 418 U.S. 24 (1974); disponible en http://www.justia.us/ us/418/24/case.html. El apartado segundo de la Enmienda XIV dice: "2. Los representantes se distribuirán proporcionalmente entre los diversos Estados de acuerdo con su población respectiva, en la que se tomará en cuenta el número total de personas que haya en cada Estado, con excepción de los indios que no paguen contribuciones. Pero cuando a los habitantes varones de un Estado que tengan veintiún años de edad y sean ciudadanos de los Estados Unidos se les niegue o se les coarte en la forma que sea el derecho de votar en cualquier elección en que se trate de escoger a los electores para Presidente y Vicepresidente de los Estados Unidos, a los representantes del Congreso, a los funcionarios ejecutivos y judiciales de un Estado o a los miembros de su legislatura, excepto con motivo de su participación en una rebelión o en algún otro delito, la base de la representación de dicho Estado se reducirá en la misma proporción en que se halle el número de los ciudadanos varones a que se hace referencia, con el número total de ciudadanos varones de veintiún años del repetido Estado" (énfasis añadido).

83 "Articulo 38. Los derechos o prerrogativas de los ciudadanos se suspenden: ... ii. Por estar sujeto a un proceso criminal por delito que merezca pena corporal, a contar desde la fecha del auto de formal prisión.... El Tribunal Electoral explica esta figura jurídica con las siguientes palabras: “... el referido auto de formal prisión es aquella resolución judicial dictada por el órgano jurisdiccional al vencer el término de setenta y dos horas, mediante la cual, previa reunión de los datos que sean suficientes para comprobar el cuerpo del delito y que exista presunta responsabilidad del inculpado, se emite prisión preventiva en su contra y, por lo tanto, se le sujeta a un proceso penal, con lo cual, se fija la materia por la que se ha de seguir el mismo; debiéndose precisar que el objeto de dicho auto de formal prisión no se limita a la detención, sino que habrá de tener algunas otras consecuencias como: ... d) suspende los derechos y prerrogativas del ciudadano, en términos de la fracción II del artículo 38 de la Constitución General de la República".

${ }^{84}$ Véase el caso "Pedraza Longi" (SUP-JDC-85/2007) y el análisis, en el contexto de la teoría garantista, que realiza Salazar Ugarte, Pedro, "Dos versiones de un garantismo espurio en la jurisprudencia mexicana”, en Salazar Ugarte et al., Garantismo espurio, Madrid, Fundación Coloquio Jurídico Europeo, 2009, pp. 58 y ss. 
Si no está expresamente incluida esta limitación del derecho fundamental en la Constitución, la suspensión del sufragio puede ser acordada por el poder público si existe una habilitación para ello en la norma fundamental, que suele exigir la aprobación de una norma con rango de ley, donde se fije de manera expresa, precisa y previsible el límite en cuestión, y todo ello con el fin exclusivo de proteger otros derechos o bienes constitucionales. ${ }^{85}$

En palabras del Tribunal Europeo de Derechos Humanos (Hirst c. Reino Unido, núm. 2): ${ }^{86}$

Las eventuales restricciones no menoscabarán los derechos en aspectos esenciales, privándoles de su contenido y eficacia; responderán a un fin legítimo y los medios empleados no resultarán desproporcionados (Mathieu-Mohin y Clerfayt c. Bélgica..., \$ 52). En particular, ninguna de las condiciones impuestas pueden afectar a la libre expresión del pueblo para la elección del poder legislativo; dicho de otra manera, deben reflejar, y

${ }^{85}$ El Legislador argentino ha previsto en el Código Electoral Nacional (artículo 3.d) la privación del sufragio a los condenados por delitos dolosos a pena privativa de libertad, pero la Corte Suprema de Justicia ha considerado inconstitucional la privación referida a las personas detenidas sin condena (Sentencias de 27 de septiembre de 2001 y 9 de abril de 2002), http://www.csjn.gov.ar/.

La Corte Constitucional de Colombia "ha señalado que las normas que niegan el derecho al sufragio a las personas condenadas, se encuentran acordes con el texto constitucional. Al respecto la Corporación expresó los siguiente: “... el derecho político al sufragio no se concreta en su ejercicio actual y efectivo sino bajo la condición indispensable de hallarse en ejercicio de la ciudadanía, luego quien está afectado con la suspensión de la ciudadanía, ya sea de hecho, por no cumplir los requisitos exigidos, o en virtud de decisión judicial en los casos que determine la ley (C.P. artículo 98), está excluido de la posibilidad de elegir y ser elegido y de ejercer los derechos políticos allí consignados... "La Constitución permite que la ciudadanía se suspenda en virtud de decisión judicial "en los casos que determine la ley", como es por ejemplo, el presente caso, en que ella se produce a título de pena por la comisión de un delito, por medio de sentencia debidamente ejecutoriada. En consecuencia, no encuentra fundamento el cargo de la demanda, pues las normas de rango legal objeto de censura simplemente son concreción de aquella norma constitucional... Ahora bien, en la medida en que es la misma Constitución la que lo autoriza la suspensión el ejercicio de la ciudadanía y, por ende, el ejercicio de los derechos políticos que tal calidad conlleva (arts. 40, 98 y 99 C. P.), no es posible en consecuencia considerar que se vulnere el carácter democrático, participativo y pluralista del Estado Social de derecho que nos rige por el hecho de que se restrinjan en las circunstancias ya anotadas la posibilidad de ejercer funciones públicas" (Sentencia C-329/03, de 29 de abril de 2003), en http://www.ramajudicial.gov.co/csj_portal/.

${ }^{86}$ http://cmiskp.echr.coe.int/. 
no contravenir, la integridad y efectividad de un procedimiento electoral dirigido a expresar la voluntad popular a través del sufragio universal. Se puede, por ejemplo, fijar una edad mínima para asegurar que las personas que participen en el proceso electoral sean suficientemente maduras o incluso, en determinadas circunstancias, la elegibilidad puede someterse a criterios tales como la residencia para acreditar que las personas que se presenten tengan relaciones suficientemente estrechas o continuadas con el país en cuestión (Hilbe c. Liechtenstein, no. 31981/96, CEDH 1999-VI, Melnitchenko c. Ucrania, no. 17707/02, \$56, CEDH 2004-X). Cualquier limitación al principio de sufragio universal corre el riesgo de socavar la legitimidad democrática del poder legislativo así elegido y de las leyes que apruebe. En consecuencia, la exclusión de cualesquiera grupos o categorías de población debe conciliarse con los principios que sustenta el artículo 3 del Protocolo $\mathrm{n}^{\circ} 1$ (véase, mutatis mutandis, Aziz c. Chipre, núm. 69949/01, §28, CEDH 2004-V).

El Tribunal Europeo de Derechos Humanos no excluye que se impongan restricciones a los derechos electorales de la persona que, por ejemplo, ha cometido graves abusos en el ejercicio de funciones públicas o cuyo comportamiento amenaza con socavar el Estado de derecho o los fundamentos de la democracia. No obstante, no se pueden adoptar a la ligera medidas rigurosas como la privación del derecho de voto y la imposición legal de una restricción global a todos los presos que cumplan su pena, que se les aplique automáticamente, cualquiera que sea la duración de su condena e independientemente de la naturaleza y gravedad de la infracción cometida y de su situación personal, sobrepasa el margen de apreciación aceptable, por amplio que sea, y es incompatible con el artículo 3o. del Protocolo núm. $1 .^{87}$

A nuestro juicio, la aplicación del principio democrático tendría que conducir a la inexistencia de restricciones políticas a los presos, al menos en todos aquellos ámbitos en los que el ejercicio de los derechos es compatible con su situación administrativa de sujeción especial, y el sufragio lo es sin especiales dificultades; por utilizar las categorías de Michael Walzer, no sería justo que un ciudadano ubicado en una esfera pueda ser coartado por ubicarse en otra esfera, con

87 Véase, en general, el estudio de Bernal Pulido, Carlos, El principio de proporcionalidad y los derechos fundamentales..., cit. 
respecto a un bien distinto, ${ }^{88}$ y el preso está en una esfera caracterizada por la restricción de su libertad personal en la que no se encuentran los que no han delinquido, pero esta diferencia de posiciones no debe trasladarse a la esfera política, al menos al derecho de sufragio, porque en esta última la desigualdad carecería de justificación.

Como ya hemos visto antes, en todo derecho fundamental, y el voto lo demuestra con claridad, puede diferenciarse una dimensión subjetiva y una dimensión objetiva, y de la dimensión objetiva de las normas que garantizan el derecho fundamental al sufragio se derivan los efectos irradiante y recíproco de este derecho. En lo que al derecho de sufragio se refiere, el efecto de irradiación puede tener especial incidencia en el derecho penal, lo que significará que el legislador penal deberá actuar de manera que no ignore el contenido esencial del derecho, lo que ocurrirá si aprueba una disposición sancionadora que con carácter general priva a una determinada categoría de personas del ejercicio del derecho de voto. ${ }^{89}$

Por su parte, el efecto recíproco obliga al legislador a que en su labor limitativa observe el respeto debido a los términos constitucionales que mediatizan su tarea y, en segundo lugar, a que esta última no sea arbitraria o no razonable.

La aplicación de estos efectos al derecho de voto nos permite concluir, por citar un ejemplo, que, con arreglo a la Constitución Española de 1978, es inconstitucional la privación del derecho de voto a los presos, pues la persona que cumple una condena privativa de libertad no carece de capacidad para autodeterminarse políticamente y, además, esa circunstancia no convierte a quien se encuentra en ella en una persona carente de dignidad, por lo que la sanción consistente en la privación del sufragio activo por ese motivo no es en absoluto compatible con el mandato contenido en el artículo 25.2 de la Constitución..$^{90}$

${ }^{88}$ Spheres of Justice, Nueva York, Basic Books, 1983, p. 19; en la versión castellana, Las esferas de la justicia. Una defensa del pluralismo y la igualdad, México, Fondo de Cultura Económica, 1993; sobre este particular, pp. 32 y 33.

${ }^{89}$ Véase Minister of Home Affairs v. National Institute for Crime Prevention and ReIntegration of Offenders (Nicro) and others, http://www.constitutionalcourt.org.za/site/ home.htm.

90 "Las penas privativas de libertad y las medidas de seguridad estarán orientadas hacia la reeducación y reinserción social y no podrán consistir en trabajos forzados. El condenado a pena de prisión que estuviere cumpliendo la misma gozará de los derechos fundamentales de este Capítulo, a excepción de los que se vean expresamente limitados por el contenido del fallo condenatorio, el sentido de la pena y la ley penitenciaria. En 
Por otra parte ni apelando a razones técnicas se puede justificar que los reclusos no puedan votar, pues es un problema fácilmente solucionable a través del voto por correo.

Por este motivo, entendemos que se ha acertado al convertir en historia la privación del derecho de sufragio activo como consecuencia de una sanción penal. ${ }^{91}$ Antes de la entrada en vigor del Código Penal de 1995, esta consecuencia se podía producir bien por razón de una inhabilitación absoluta (artículo 35), una inhabilitación especial (artículo 37) o una suspensión (artículo 39)..$^{22}$ La primera y la tercera eran penas accesorias a las de privación de libertad, mientras que la segunda era una pena específica. ${ }^{93}$

A la misma conclusión han llegado, por mencionar otros dos ordenamientos distantes y distintos, el Tribunal Supremo de Canadá y el Tribunal Supremo de Sudáfrica; el primero (Sauvé c. Canadá, del 31 de octubre de 2002) defiende que una interpretación amplia del objeto es particularmente importante en el derecho de voto, sin que deba ser limitado por intereses colectivos opuestos. Los derechos democráticos fundamentales no constituyen "una gama de soluciones aceptables"

todo caso, tendrá derecho a un trabajo remunerado y a los beneficios correspondientes de la Seguridad Social, así como al acceso a la cultura y al desarrollo integral de su personalidad".

91 Había cuestionado la constitucionalidad de esta sanción, vigente hasta la entrada en vigor del Código Penal de 1995, Luis López Guerra en su estudio "El derecho de participación del artículo 23.2 de la Constitución Española”, Los derechos fundamentales y libertades públicas, XIII Jornadas de Estudio de la Dirección General del Servicio Jurídico del Estado, Madrid, 1993; véanse las pp. 1177 y 1178.

${ }_{92}$ Según el antiguo artículo 35.2: "La pena de inhabilitación absoluta producirá los efectos siguientes: $2^{\circ}$. La privación del derecho de elegir y ser elegido para cargas públicos durante el tiempo de la condena..."; "La inhabilitación especial para el derecho de sufragio privará al penado del derecho de elegir y ser elegido durante el tiempo de la condena para el cargo electivo sobre que recayere" (artículo 37); "La suspensión del derecho de sufragio privará al penado, igualmente, de su ejercicio durante el tiempo de la condena” (artículo 39).

${ }^{93}$ En la Disposición Derogatoria del Código Penal de 1995 se derogan de manera expresa los términos "activo y" del artículo 137 de la LOREG ("Por todos los delitos a que se refiere este Capítulo se impondrá, además de la pena señalada en los artículos siguientes, la de inhabilitación especial para el derecho de sufragio activo y pasivo"). Habrá que entender también derogada la letra a) del artículo 3 ("Carecen de derecho de sufragio: los condenados por sentencia judicial firme a la pena principal o accesoria de privación del derecho de sufragio durante el tiempo de su cumplimiento"), ya que tal pena no existe; véase al respecto el estudio de Pozuelo Pérez, Laura, Las penas privativas de derechos en el Código Penal, Madrid, Colex, 1998, pp. 14 y 15. 
entre las que el legislador pueda elegir a su antojo, pues los derechos no son una cuestión de privilegio o de mérito, sino de pertenencia a la sociedad, lo que es especialmente cierto en el derecho de sufragio, piedra angular de la democracia. ${ }^{94}$

Por su parte, el Tribunal Constitucional de Sudáfrica afirmó (August $c$. Electoral Commission, del 1o. de abril de 1999) que el derecho de voto impone obligaciones positivas tanto al legislador como al Ejecutivo, insistiendo en que el sufragio universal de los adultos es uno de los valores fundamentales de todo el sistema constitucional porque es importante no sólo para la soberanía popular y la democracia sino también como símbolo de la dignidad e identidad individual. "Literalmente, significa que todo el mundo es importante.". ${ }^{9}$

${ }^{94}$ http://scc.lexum.umontreal.ca/fr/2002/2002csc68/2002csc68.html. http://scc.lexum. umontreal.ca/en/2002/2002scc68/2002scc68.html.

${ }_{95}$ http://www.constitutionalcourt.org.za/site/home.htm y http://www.saflii.org/za/case s/ZACC/1999/3.pdf. 